

\title{
Workforce and Economic Development Considerations from the Operations and Maintenance of Wind Power Plants
}

Matthew Kotarbinski, David Keyser, and Jeremy Stefek

National Renewable Energy Laboratory

NREL is a national laboratory of the U.S. Department of Energy

Office of Energy Efficiency \& Renewable Energy

Operated by the Alliance for Sustainable Energy, LLC

This report is available at no cost from the National Renewable Energy Laboratory (NREL) at www.nrel.gov/publications.
Technical Report

NREL/TP-5000-76957

December 2020 


\section{BNREL}

\section{Workforce and Economic Development Considerations from the Operations and Maintenance of Wind Power Plants}

Matthew Kotarbinski, David Keyser, and Jeremy Stefek

National Renewable Energy Laboratory

\section{Suggested Citation}

Kotarbinski, Matthew, David Keyser, and Jeremy Stefek. Workforce and Economic Development Considerations from the Operations and Maintenance of Wind Power Plants. Golden, CO: National Renewable Energy Laboratory. NREL/TP-5000-76957. https://www.nrel.gov/docs/fy210sti/76957.pdf.

NREL is a national laboratory of the U.S. Department of Energy Office of Energy Efficiency \& Renewable Energy Operated by the Alliance for Sustainable Energy, LLC

This report is available at no cost from the National Renewable Energy Laboratory (NREL) at www.nrel.gov/publications.

Contract No. DE-AC36-08GO28308
Technical Report

NREL/TP-5000-76957

December 2020

National Renewable Energy Laboratory 15013 Denver West Parkway Golden, CO 80401 303-275-3000 • www.nrel.gov 


\section{NOTICE}

This work was authored by the National Renewable Energy Laboratory, operated by Alliance for Sustainable Energy, LLC, for the U.S. Department of Energy (DOE) under Contract No. DE-AC3608GO28308. Funding provided by U.S. Department of Energy Office of Energy Efficiency and Renewable Energy Wind Energy Technologies Office. The views expressed herein do not necessarily represent the views of the DOE or the U.S. Government.

This report is available at no cost from the National

Renewable Energy Laboratory (NREL) at

www.nrel.gov/publications.

U.S. Department of Energy (DOE) reports produced

after 1991 and a growing number of pre-1991

documents are available

free via www.OSTI.gov.

Cover Photos by Dennis Schroeder: (clockwise, left to right) NREL 51934, NREL 45897, NREL 42160, NREL 45891, NREL 48097, NREL 46526.

NREL prints on paper that contains recycled content. 


\section{Acknowledgments}

This work was supported by the U.S. Department of Energy (DOE) under Contract No.

DEAC36-08GO28308 with the National Renewable Energy Laboratory (NREL). Funding for the work was provided by the DOE Office of Energy Efficiency and Renewable Energy, Wind Energy Technologies Office. The authors would like to thank Maggie Yancey, Patrick Gilman, and Rich Tusing (DOE) for reviewing and supporting this report.

BW Research Partnership performed data collection and supported this research effort. The authors would like to thank Josh Williams, Ryan Young, and Mitchell Schirch for their assistance with survey design, data collection, and analysis for this research project.

For their peer reviews, the authors thank Katie Siegner of Rocky Mountain Institute, as well as Eric Lantz and Rob Hammond (NREL).

In addition, for their review, we thank Brian Smith, and Daniel Laird of (NREL). The authors are grateful for Sheri Anstedt and Deanna Cook's editorial support. Lastly, the authors would like to thank Adam Stern of the American Wind Energy Association.

This report would not have been possible without the contributions from many wind power plant operators who provided insights in support our research. The authors would also like to thank all of the wind plant employees who completed the employee-level survey. 


\section{List of Acronyms}

EIA

FTE

MW

NREL

O\&M
U.S. Energy Information Administration

full-time equivalent (job)

megawatt

National Renewable Energy Laboratory

operation and maintenance 


\section{Executive Summary}

As wind capacity in the United States grows, economic opportunities also emerge - supported by the development of the wind workforce, specifically in the operation and maintenance (O\&M) phase. Moreover, almost all wind turbines in the United States - about $99 \%$ - are located in rural areas (American Wind Energy Association 2018). Communities in these rural areas can anticipate some degree of economic impact from the wind industry. However, the various stakeholders within these communities, such as local businesses and government officials, are not always fully informed of the workforce impacts caused by wind power plants during operational years (Stefek et al. 2019). Although several research studies have focused on workforce and economic impacts of land-based wind facilities (e.g., Tegen et al. 2014; Brown et al. 2012; Halvatzis and Keyser 2013), these studies focused on the quantity of workers and not on O\&M workforce interactions with local communities, such as worker commuting and spending patterns. This report is intended to provide stakeholders and community decision makers with qualitative and quantitative information to enable informed decisions that support workforce planning around new wind energy deployment.

The existence of a wind power plant has workforce and economic considerations for the local surrounding regions. This study illustrates that a wind plant's various characteristics, including geography, age of plant, rated capacity, and number of turbines, all influence workforce requirements.

- For the entire U.S. fleet of land-based wind plants, we estimate that one full-time equivalent (FTE) O\&M worker is required for every seven turbines, or 0.086 FTE per 1 megawatt (MW) of installed capacity. This equates to 8,204 O\&M-specific workers for the 94,971 MW of operational wind capacity in the United States as of November 2019.

- Depending on where a wind plant is located, the geographical traits of each region will dictate the workforce needs of that plant. In regions with less population density and greater land availability, wind facilities with higher nameplate capacities are more prevalent. These wind facilities tend to have more turbines, which require a larger O\&M workforce because of the increased servicing needs.

- The age of a wind power plant impacts workforce needs. Wind plants commissioned before 2000 require a larger workforce than wind facilities commissioned in or after 2000. Wind plants commissioned before 2000 require a larger O\&M workforce, on average 13 more O\&M workers than a wind facility commissioned after 2000.

- As the rated capacity of a wind plant increases, so too, does the required workforce. Wind plants with a maximum rated capacity of $19 \mathrm{MW}$ frequently employ two or fewer employees. Wind plants with a rated capacity of more than $200 \mathrm{MW}$ typically employ at least six full-time permanent employees, but on average employ more than 16 employees. 
Furthermore, a wind plant's O\&M workforce impacts the local and surrounding communities in the following quantitative and qualitative ways:

- Based on the 11 wind plants that participated in the BW Research survey, for every 1 MW of installed capacity, a local community can expect 0.11 direct FTE positions to support the wind plant. Additionally, local communities can expect 0.33 indirect and 0.06 induced FTE positions for every $1 \mathrm{MW}$ of installed capacity to support other businesses and services within the community.

- An O\&M labor force is a source of economic development in nearby communities in the form of business revenue and generated tax revenue. Based on our employee survey results, $80 \%$ of workers spend money in the community they work in, and $87 \%$ spend most of their money where they live. This economic activity is expected to sustain over the operating wind plant's life span, which lasts between 20 and 25 years.

- Where a worker lives in relation to a wind plant depends on a few factors including distance to the wind plant, what housing and service options are available surrounding the wind plant, and the type of employment structure that is utilized by the wind plant operator.

- Lastly, this report finds that in addition to O\&M jobs and tax revenue, communities may receive further economic impacts through "developer community investments," which can include donations, funds for local infrastructure, and community programs. 


\section{Table of Contents}

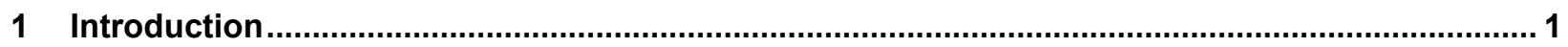

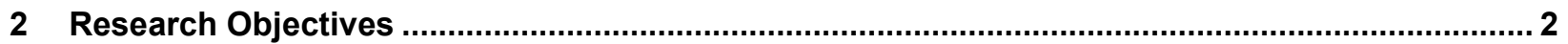

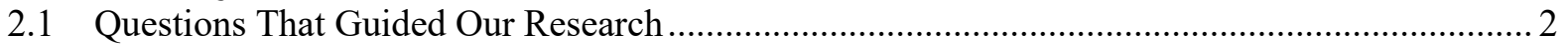



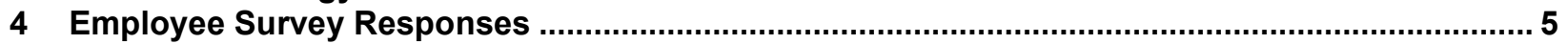

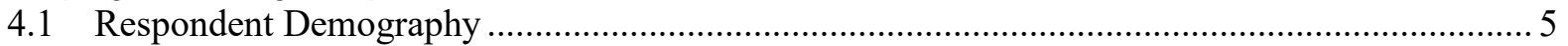



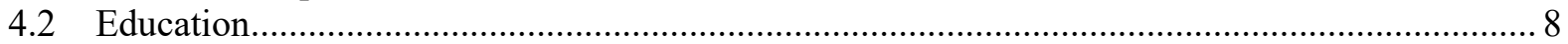

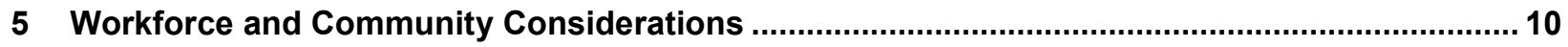

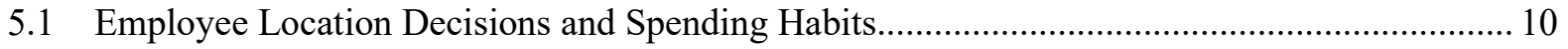

5.2 Population Centers Effect on Wind Plant Worker Locations.................................................... 14

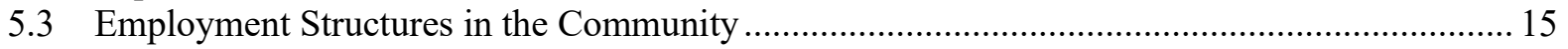

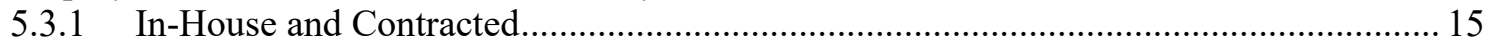

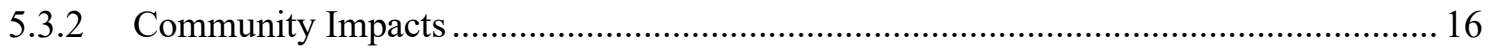

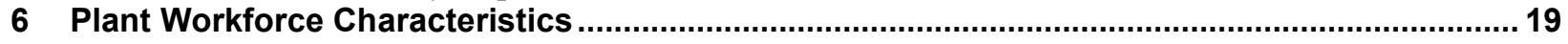

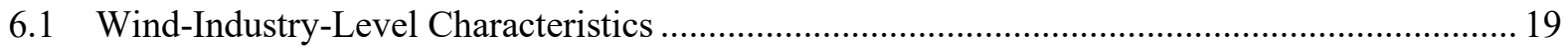

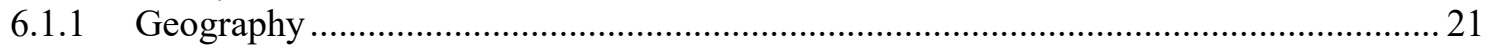

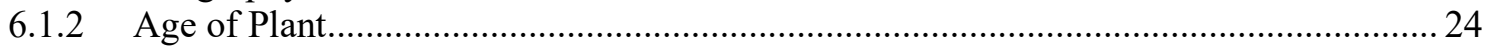

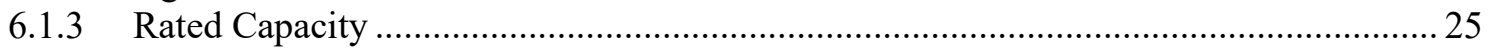

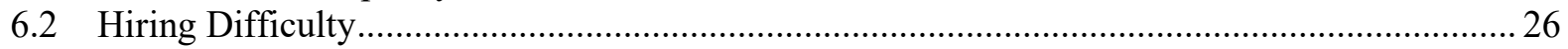



8 Modeled Wind Plant Economic Community Impacts............................................................. 30

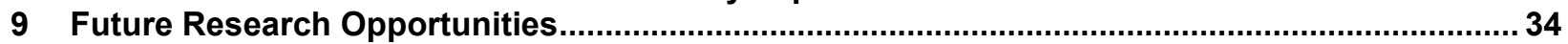

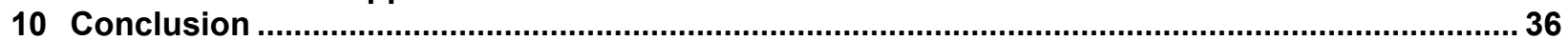

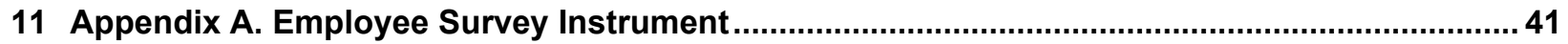

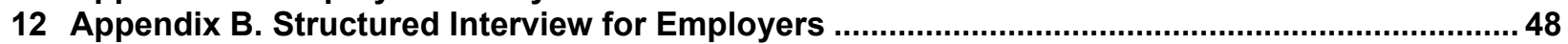

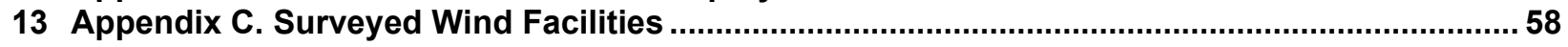




\section{List of Figures}

Figure 1. U.S. Census Regions and wind resource data (100-meter hub height)..................................... 3

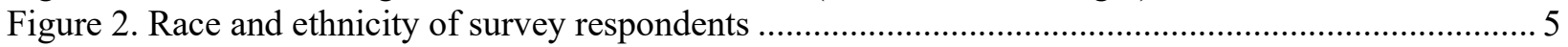

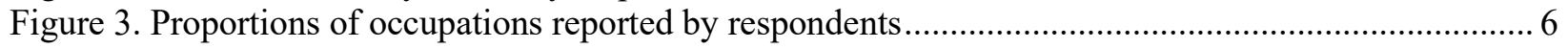

Figure 4. Respondents experience based on employment length with current employer ........................... 7

Figure 5. Employee experience in the wind industry in general.......................................................... 8

Figure 6. Employee agreement with their expected career pathway in the wind industry over the next 5

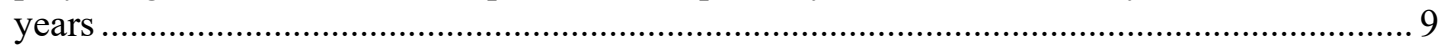

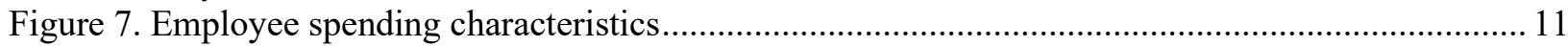

Figure 8 . Those who chose to locate because of family have a tendency to have longer commutes than those who chose their community for other reasons .......................................................... 12

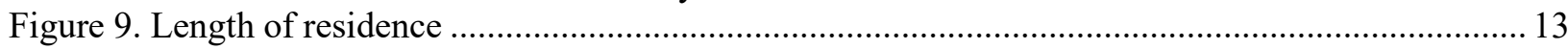

Figure 10. Population centers (blue) and location of where O\&M workers live (green) at two different



Figure 11. More operators responded that they utilize contracted labor structures rather than in-house

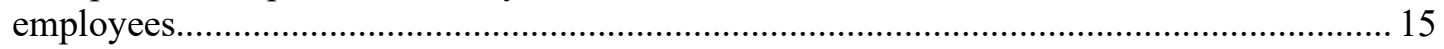

Figure 12. In-house and contract worker responses to community-related questions ............................. 17

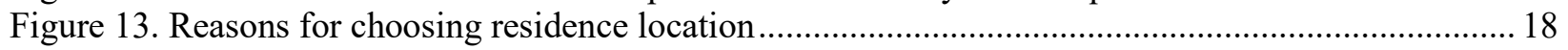

Figure 14. Average employment estimate across U.S. wind power plant fleet ....................................... 21

Figure 15. Average wind power plant employment based on census region............................................ 23

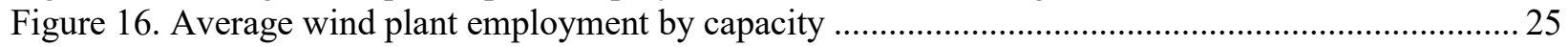

Figure 17. The average and range of indirect and induced jobs in the sample ...................................... 32

\section{List of Tables}

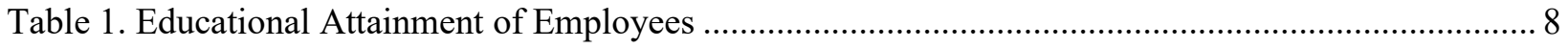

Table 2. Turbine and Installed Capacity Metrics for Population and Land Area ................................... 22

Table 3. Wind Power Plant Characteristics by Age and Geographic Region ............................................ 24

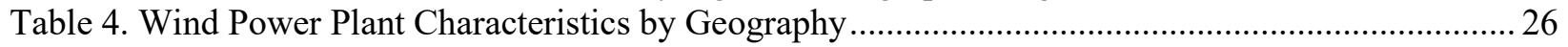

Table 5. Average Estimated O\&M County-Level Impacts of Wind Plants Sampled ................................ 31

Table 6. Value-Added Gross Domestic Product and Taxes from Wind Plant O\&M ............................... 32

Table 7. Direct Tax Payments per Megawatt of Capacity …...................................................................... 33

Table 8. Direct Tax Payments per Tower ....................................................................................... 33 


\section{Introduction}

The expansion of wind capacity across the United States has led to an increase in operation and maintenance $(\mathrm{O} \& \mathrm{M})$ workforce requirements. As the wind energy industry continues to grow, so do the economic opportunities supported by the development of the wind workforce. About $99 \%$ of the entire fleet of wind turbines is located in rural areas of the United States; therefore, we expect these rural communities to experience some degree of economic impact from the wind industry (American Wind Energy Association 2018). However, various stakeholders within rural communities, including local businesses, residents, and government officials who could be impacted by wind development, are not always fully informed of the workforce impacts caused by wind power plants during their construction and operational years (Stefek et al. 2019).

Land-based wind deployment in the United States grew at an annual average of 13\% from 2008 to 2018 (U.S. Energy Information Administration [EIA] 2019a), alongside an increase in wind energy employment. In 2018, wind energy generated $6.6 \%$ of U.S. electricity, the highest among renewables (EIA 2019c). During this time and when compared to the previous year, the wind industry employed 111,200 workers, growing at a rate of $4 \%$, which equates to approximately 3,700 jobs. Of these workers, approximately 36,700 were related to construction and 26,500 were related to manufacturing. However, workers within the O\&M sector have not been grouped within their own category (National Association of State Energy Officials and Energy Futures Initiative 2019).

Using data from surveys and the EIA, this report establishes that 8,204 wind workers were employed full time in wind energy O\&M nationwide in 2018, as opposed to construction or manufacturing. ${ }^{1}$ With an understanding of these workforce implications, local communities are then able to make greater informed decisions on occupational availability, housing requirements, commuting impacts, as well as increased local demands for goods and services.

Numerous publications, such as Tegen et al. (2014), Brown et al. (2012), and Halvatzis and Keyser (2013), have attempted to quantify wind energy employment and other economic impacts of land-based wind facilities. This research has largely focused on the quantity of workers, rather than analyzing the greater economic implications that concern local community stakeholders. Few studies consider O\&M workforce interactions with local communities, such as understanding worker commuting patterns, community interactions, housing stock options, earnings, and where workers spend these earnings.

This report aims to better understand the qualitative and quantitative impacts of O\&M workers who may reside in communities near utility-scale, land-based wind power plants. This report also updates existing economic impact research, providing detailed information on the regional characteristics that affect land-based wind O\&M employment. This information could then be used by stakeholders in communities where wind development may occur to plan for future community growth.

\footnotetext{
${ }^{1}$ O\&M employment estimate is for 94,971 MW, based on the installed wind capacity reported on Form EIA-860, as of September 2019 which lists wind plants installed in 2018.
} 


\section{Research Objectives}

The purpose of this study was to gain a clearer understanding of how the O\&M workforce engages with the local surrounding area of a wind plant during the operational years of that facility. Researchers at the National Renewable Energy Laboratory (NREL) developed a series of key research questions to gain insight into ways an O\&M workforce economically impacts local communities. This information can give community-level stakeholders and decision makers a better idea of what to expect and how to maximize any economic development impacts during the O\&M phase.

\subsection{Questions That Guided Our Research}

These key questions shaped our approach to collecting quantitative and qualitative data:

- How does the wind plant's O\&M workforce support local economic development? Specifically, how does where a worker chooses to live and work impact their spending habits?

- How does a wind plant's various characteristics, such as rated capacity and number of turbines, dictate workforce requirements for the facility?

- What additional extended economic impacts does a wind plant provide a rural community?

In answering these questions, we hope to increase understanding of the economic impacts of land-based wind energy during the O\&M phase of plant operation. 


\section{Data Methodology}

NREL collaborated with BW Research Partnership (BW Research) ${ }^{2}$ to develop a structured survey for representatives of land-based wind power plant operators and a survey instrument for plant employees to better understand their impact on communities.

NREL used the U.S. Wind Turbine Database to identify a set of 46 potential wind plants to survey, all of which are diverse in capacity and geography. ${ }^{3}$ These diverse characteristics are referenced to provide insights into a variety of wind plants in different regions. The geographic regions from the U.S. Census Bureau were used to establish geographic diversity. These regions are shown in Figure 1.

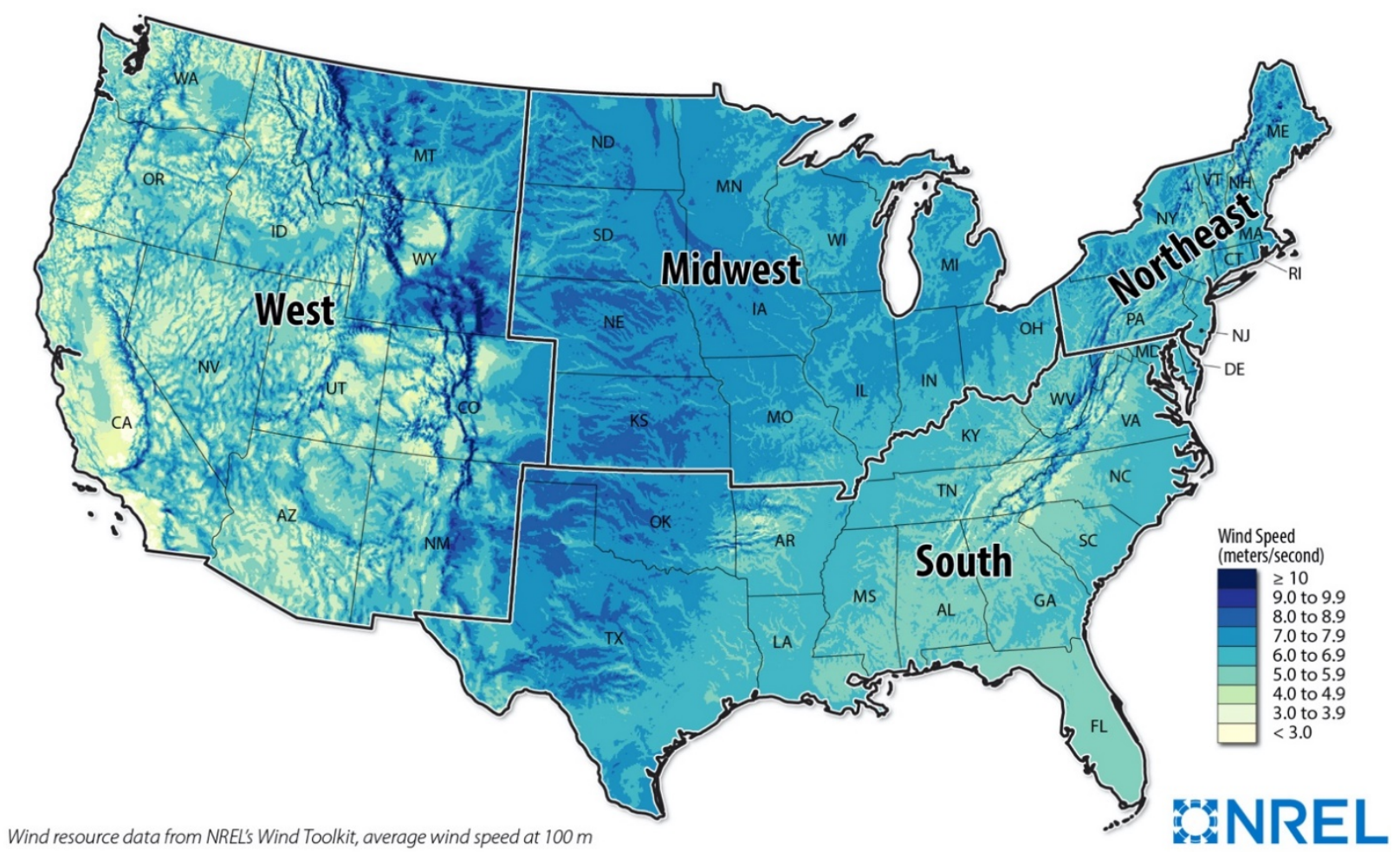

Figure 1. U.S. Census regions ${ }^{4}$ and wind resource data (100-meter hub height)

Of the 46 plants identified as possible survey participants, BW Research selected 11 as suitable plants whose representatives were willing to participate. These selections were made to maintain diversity in plant size as well as a broad-based geographic representation. To maintain

\footnotetext{
${ }^{2}$ For more information about BW Research, go to https://www.bwresearch.com/.

${ }^{3}$ The U.S. Wind Turbine Database website is available at https://eerscmap.usgs.gov/uswtdb/.

${ }^{4}$ For more information on census regions, please visit: https://www2.census.gov/geo/pdfs/mapsdata/maps/reference/us_regdiv.pdf.
} 
geographic diversity, surveyed plants had to be separated by at least 20 kilometers to avoid surveying facilities that might be clustered together within the same regions.

BW Research carried out employer and employee surveys between August 12, 2019, and September 27, 2019. In total:

- Eighteen of the 46 wind power plant operators responded to requests for employer surveys, of which 11 completed the employer survey from nine different states.

- Plant operator respondents include two in the South census region, two in the Midwest, and seven in the West.

- Employees from 6 of the 11 wind plants completed the employee survey for a total of 30 responses.

Appendices A and B contain copies of the employee-based survey instrument and structured questionnaire for employers, respectively. The employer and employee surveys informed respondents that their answers would remain confidential. No information provided in this report violates this confidentiality.

BW Research merged employer survey data with EIA data using a proprietary model to develop industrywide employment estimates based on certain plant characteristics. Qualitative questions, such as "does your wind farm provide any additional support to the community...?" are inherently subjective and could not be expanded to reflect the industry as a whole. The model only provides quantitative insights. 


\section{Employee Survey Responses}

The following section offers insight into the various characteristics of O\&M workers that completed the employee survey. The employee survey responses are just the answers given by the plant workers. Because of the small sample size relative to the industry as a whole, these responses do not necessarily reflect characteristics of the entire wind industry. However, this information does offer insight into how the O\&M workforce might interact with the surrounding communities. We can highlight trends and patterns within the following categories: demography, education, salary, occupation, and experience.

\subsection{Respondent Demography}

Of the employee survey respondents, $97 \%$ indicated that they were male and $3 \%$ were female. The majority of respondents- $83 \%$ - reported their race and ethnicity as white non-Hispanic (Figure 2). This was followed by those who identify as Hispanic or Latino of all $\operatorname{races}^{5}(7 \%)$ and Pacific Islander (3\%). These identifiers are not indicative of the gender, race, and ethnicity of the wind workforce at large, but rather show the demographics of survey respondents.

\section{"What ethnic group do you consider yourself a part of or feel closest to?"}

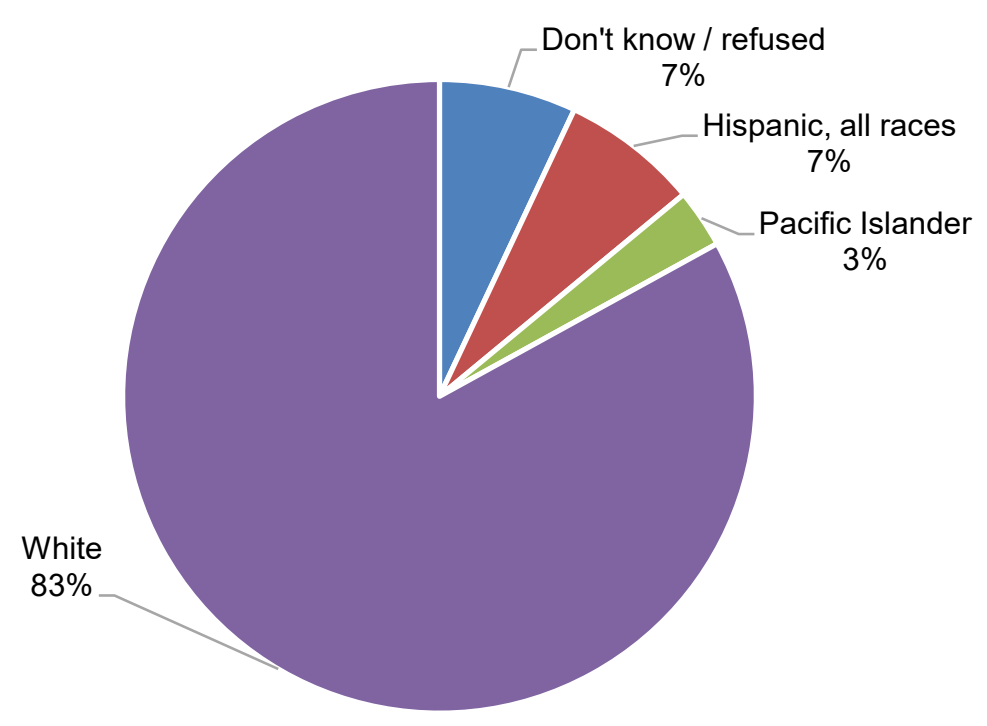

Figure 2. Race and ethnicity of survey respondents

Respondents varied in age, ranging from 21 to 61 , with an average age of 35 . This is younger than the national average of 42 (U.S. Bureau of Labor Statistics 2019).

${ }^{5}$ The U.S. Census Bureau considers Hispanic or Latino to be an ethnicity, not a race. 


\subsubsection{Occupation}

The employees surveyed were predominately wind technicians or in management, as shown in Figure 3. The average annual salary for technicians was $\$ 55,000$, whereas managers and supervisors made an average of $\$ 88,000$ annually. There were not enough responses to disclose average wages for engineering or administrative workers. These responses compare to annual average wages of $\$ 52,000$ for workers across all occupations in the United States in 2018 (U.S. Bureau of Labor Statistics 2019). ${ }^{6}$

"What is your occupation or positional title?"

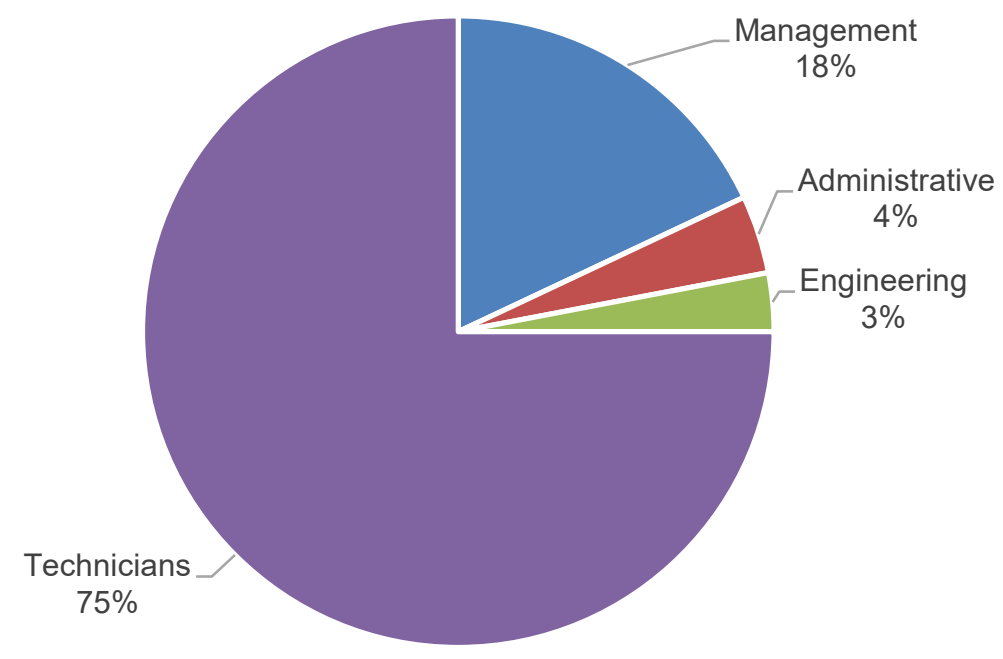

Figure 3. Proportions of occupations reported by respondents

${ }^{6}$ This number indicates average wages and salaries paid by both public- and private-sector employers. It differs from median household income, another commonly used income metric, in that household income includes all income - including retirement income and government transfer payments - that may or may not be for work performed in the year that data were collected. Household units can also include more than one person; therefore, household income is not a measurement of payments to an individual. 
Most survey respondents were either relatively experienced in their position with their current employer, having worked more than 5 years, or relatively inexperienced, having worked in their position less than a year (Figure 4). This does not mean that the workers who had been in their position less than a year were inexperienced in their occupation; it simply means that they indicated having less experience working with their current employer.

"How long have you held your current position at the facility?"

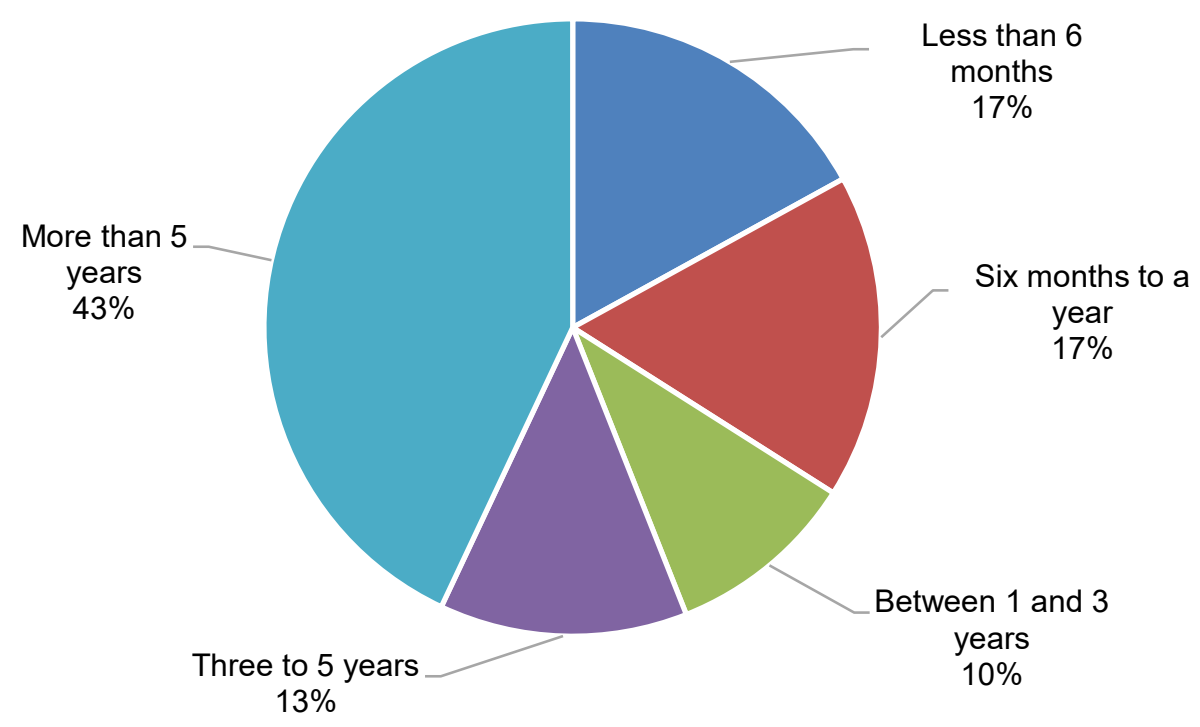

Figure 4. Respondents experience based on employment length with current employer 
Responses about whether workers' professional experience was in the wind industry in general were mixed (Figure 5). Nearly the same number of respondents "strongly disagreed" or "somewhat disagreed" (37\%) as those respondents who "strongly disagreed" or "somewhat agreed" (40\%).

"Most, if not all of my professional work experience is in the wind industry."

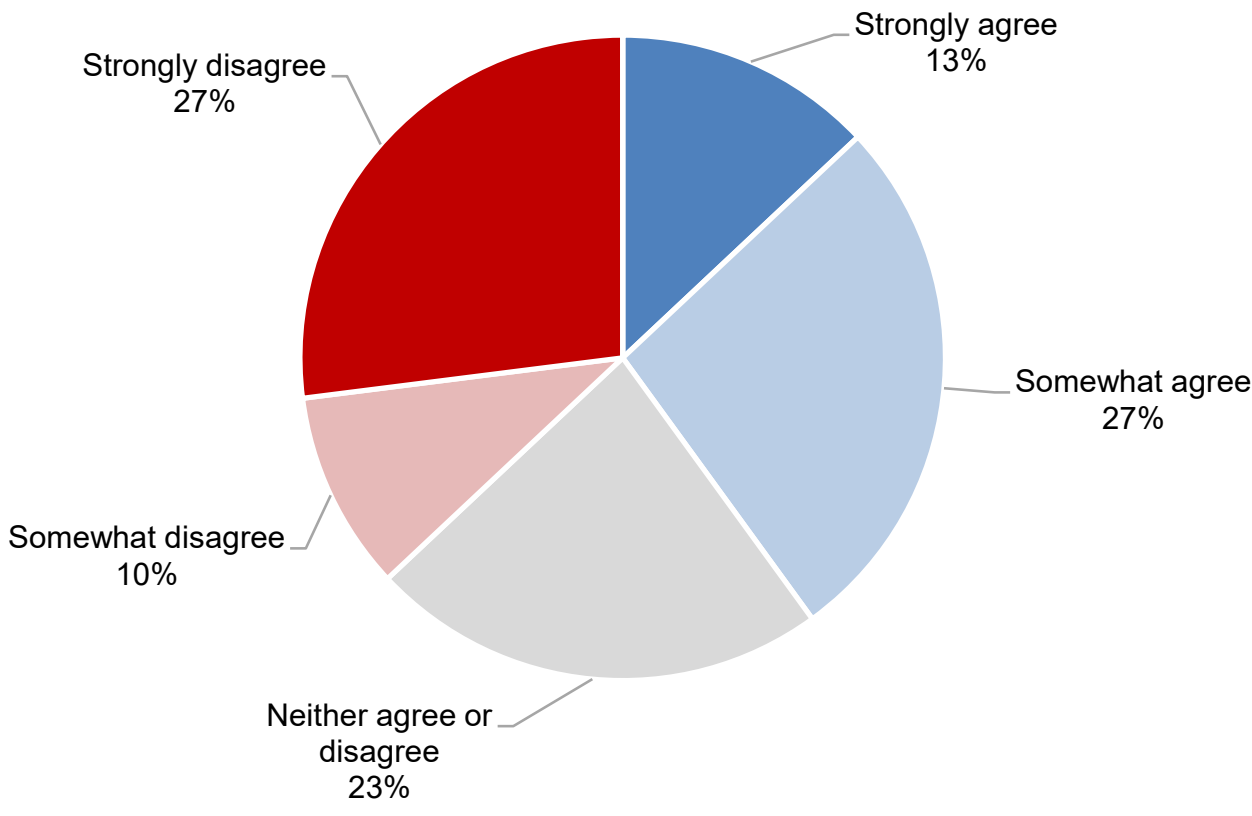

Figure 5. Employee experience in the wind industry in general

\subsection{Education}

The most common level of educational attainment cited by wind workers was a "post high school certificate or Associate Degree," as shown in Table 1. No employees reported "less than high school" or a "graduate degree."

Table 1. Educational Attainment of Employees

\begin{tabular}{|l|l|}
\hline Response percentage & Highest level of educational attainment \\
\hline $\mathbf{1 3 \%}$ & Less than high school \\
\hline $\mathbf{3 0 \%}$ & High school diploma or GED \\
\hline $\mathbf{4 3 \%}$ & Some college, no degree \\
\hline $\mathbf{1 3 \%}$ & Post high school certificate or Associate Degree (A.A. or A.S.) \\
\hline $\mathbf{0}$ & Bachelor's Degree (B.A. or B.S.) \\
\hline
\end{tabular}


Most employees did not specify whether their education was in a wind-specific degree or certificate. Of all employees who responded, $73 \%$ did not receive a wind-specific degree or certificate, and $27 \%$ did receive a wind-specific degree or certificate. For respondents who indicated their occupation as a wind technician, $40 \%$ received a wind-specific certificate or degree.

Wind employees indicated that they did see a career pathway for themselves in the wind industry (Figure 6). Nearly 77\% "strongly agreed" that they had a career pathway, an additional 13\% "somewhat agreed," and no respondents disagreed.

"I am in a career pathway in the wind industry that I expect to build upon for at least the next 5 years."

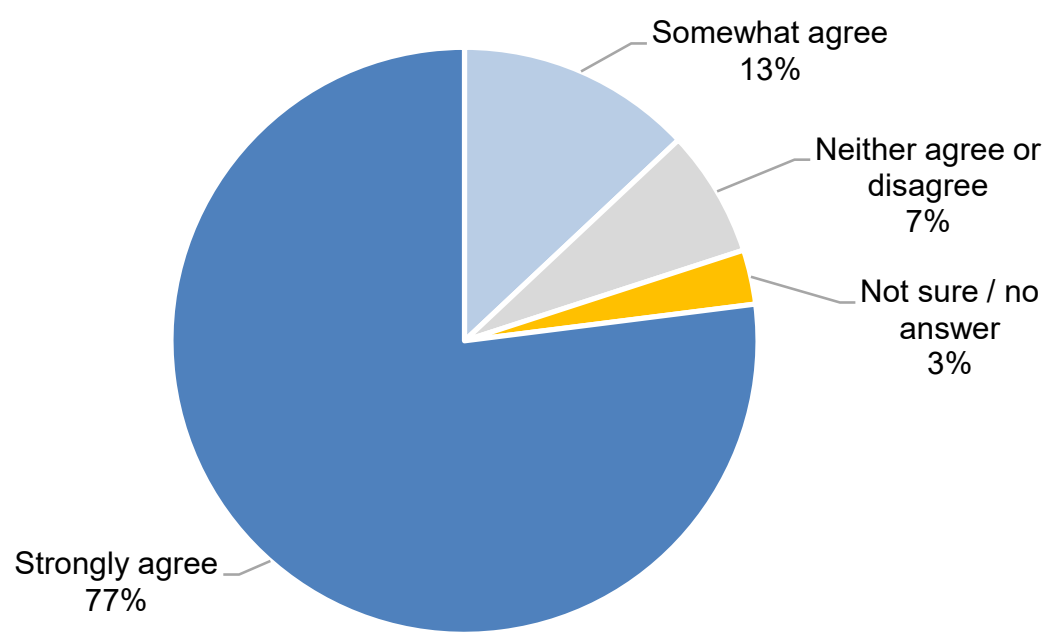

Figure 6. Employee agreement with their expected career pathway in the wind industry over the next 5 years 


\section{Workforce and Community Considerations}

A wind power plant located inside or outside of a community does not guarantee regional economic development. Workers, for example, can choose to live and spend their wages in different communities in respective proximity to the plant. Similarly, employers can choose to spend their wages within and outside of the area in which their facility is located.

A number of factors influence spending decisions. These can include the availability of goods and services needed or wanted by workers and businesses, as well as choices made by households and decision makers. If households spend most of their money where they live, then this spending is a function of their location decisions. Wind businesses make decisions to spend and invest locally based on price as well as preference and access to certain resources and supplies. All these factors impact regional economic development tied to wind power plants.

\subsection{Employee Location Decisions and Spending Habits}

We asked survey respondents two questions about their spending habits related to where they live and work. They were asked how strongly they agree or disagree with the following statements:

- "When I am not at work, I spend most of my time and money where I live."

- "When I am at work or right after work, I spend most of my time and money in the communities near the wind plant."

As shown in Figure 7, $80 \%$ of workers indicated they "agree" that they spend money in the host community during or immediately after a workday. Nearly all $-87 \%$ - respondents "somewhat agree" or "strongly agree" that they spend most of their time and money in the community where they live. ${ }^{7}$ This shows that the physical presence of wind employees operating the wind power plant is correlated with spending at local businesses and generating sales tax revenue for local governments. For example, when a wind plant worker spends their earnings at a local grocery store or restaurant, they pay a sales tax on that purchase, which then increases the local government's tax revenue.

\footnotetext{
${ }^{7}$ The definition of "community" was left up to the respondent. See Section II of Appendix A for the specific questions.
} 


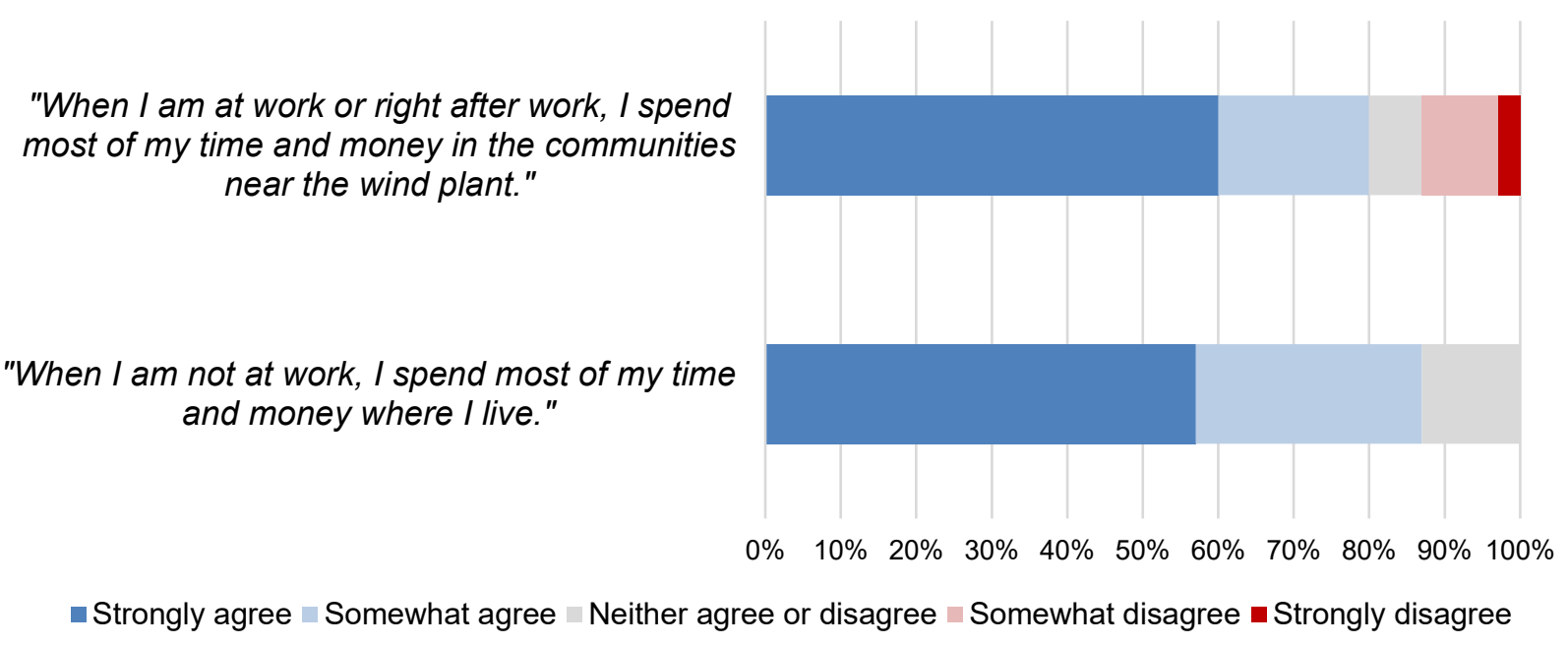

Figure 7. Employee spending characteristics

Commute time can indicate the difference between the community where an employee works and the community where they live. Most respondents, $57 \%$, indicated that they live outside of the immediate vicinity of a wind plant and have a commute of at least 30 minutes. Just over 33\% of respondents indicated a commute of less than 30 minutes.

When asked why they live where they live, the most common response did not have to do with the plant itself; rather, it was because the worker, worker's spouse, or close family member either grew up or lived in the community (Figure 8). Distance to work and liking the community in general were the second most common responses. Some respondents also mentioned amenities such as access to shopping, and others mentioned affordability. The distance from the wind plant to the nearest community would likely impact the way a wind worker defines community, as sometimes the nearest community is several miles away.

The reason for choosing to live in a particular location varied in responses. Those who chose to locate because of family have a tendency to have longer commutes than those who chose their community due to other reasons (Figure 8). 
Reasons why a worker chose a housing location with a commute of 30minutes or more from a wind plant

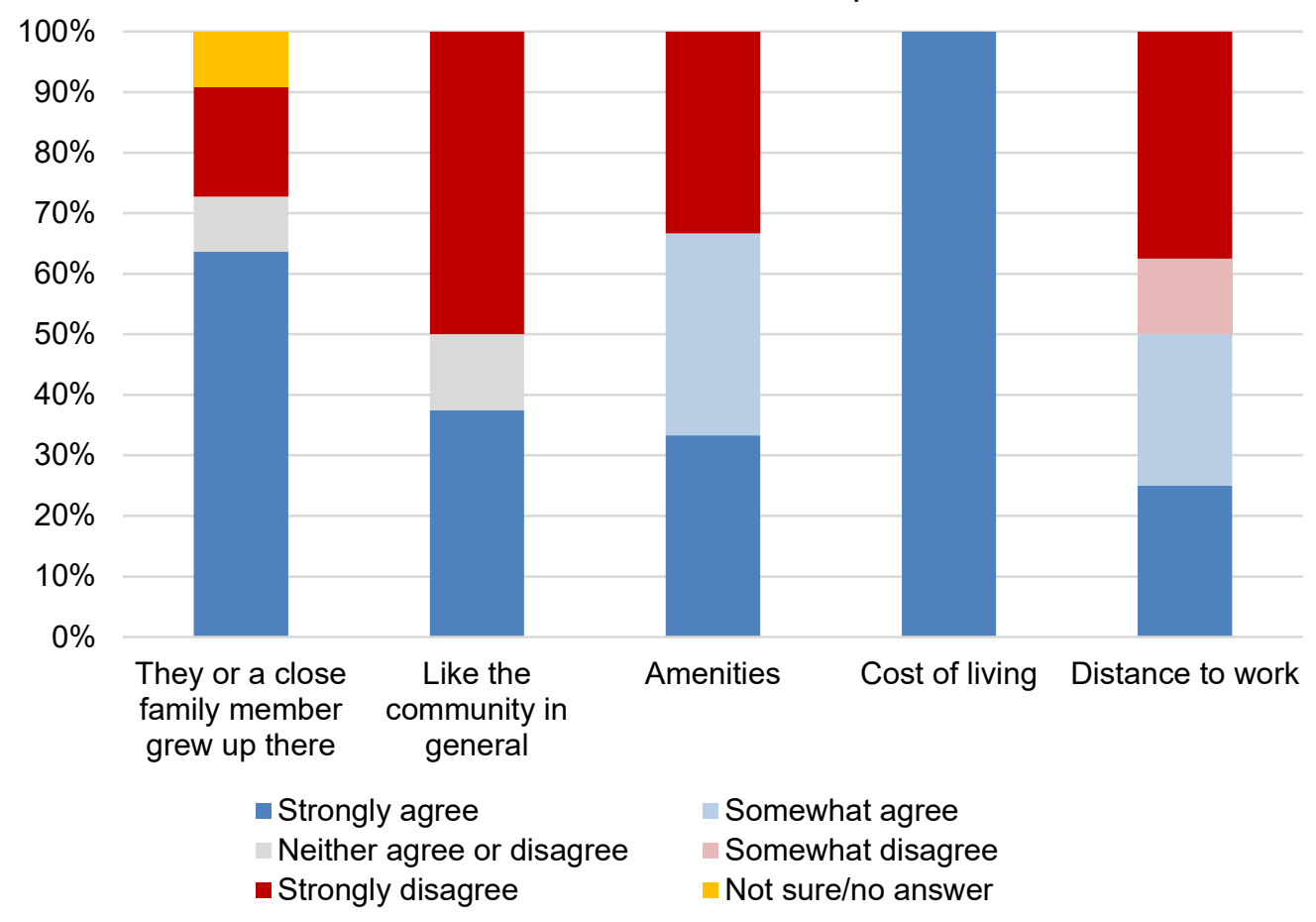

Figure 8. Those who chose to locate because of family have a tendency to have longer commutes than those who chose their community for other reasons

The most common response among those who chose their location as a result of commute time was to "strongly disagree" with the statement that they commute more than 30 minutes. An equal percentage of respondents indicate some form of disagreement (strongly or slightly) as those who indicated some form of agreement. This combination of responses implies that few wind plants within the NREL sample are located within a 30-minute commute of population centers. 
The typical (median) worker reported that they are not new to the community where they live and do not to intend to leave in the near future. The most common response was that they lived in their communities for more than 5 years and plan to stay more than 3 years (Figure 9). The majority of survey respondents indicated that they own their homes $(80 \%)$, whereas the remainder rent $(20 \%)$.

"How long have you lived in your current community in [zip code]?"

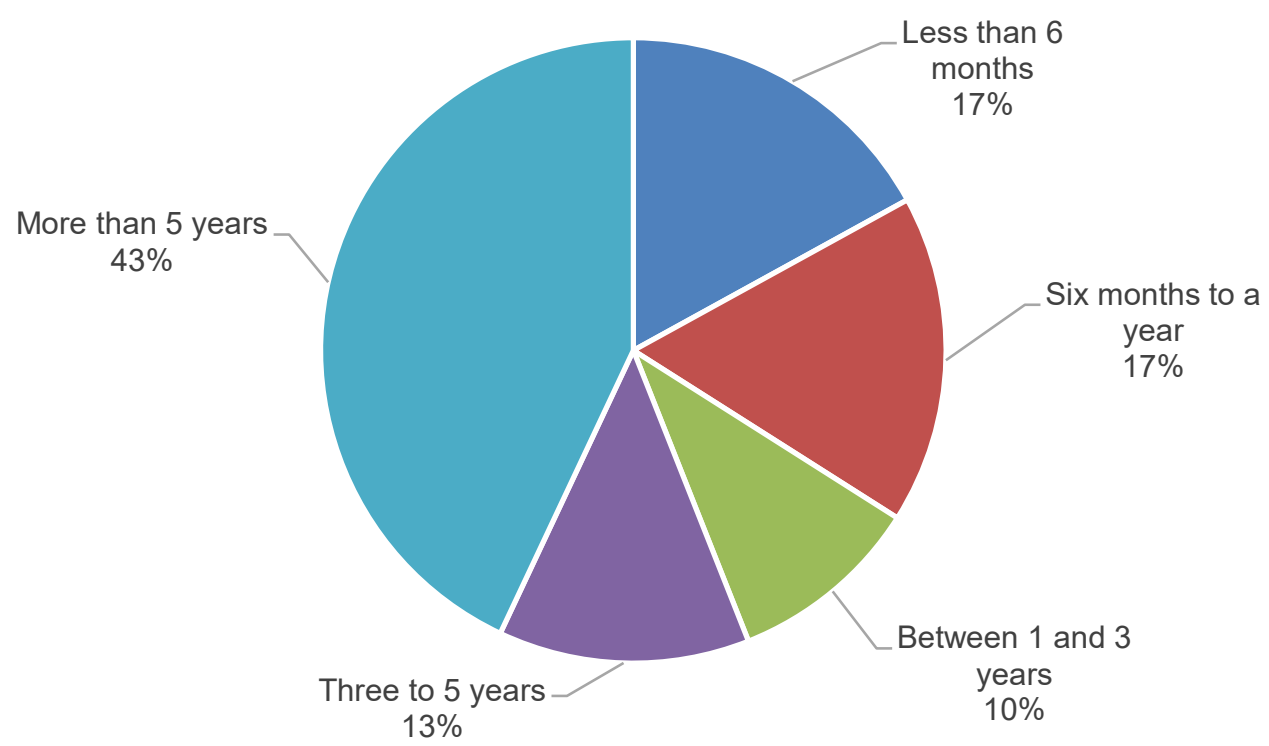

Figure 9. Length of residence 


\subsection{Population Centers Effect on Wind Plant Worker Locations}

The distribution of communities around the wind power plant may impact the distance that an O\&M worker lives from where they work. The employee survey asked wind O\&M workers to provide the zip code for their primary residence. For two wind plant locations, the zip codes could be mapped with the location of the wind plant. ${ }^{8}$ Figure 10 shows where employees live in relation to the wind plant ${ }^{9}$ and identifies communities with populations greater than 1,000 residents.

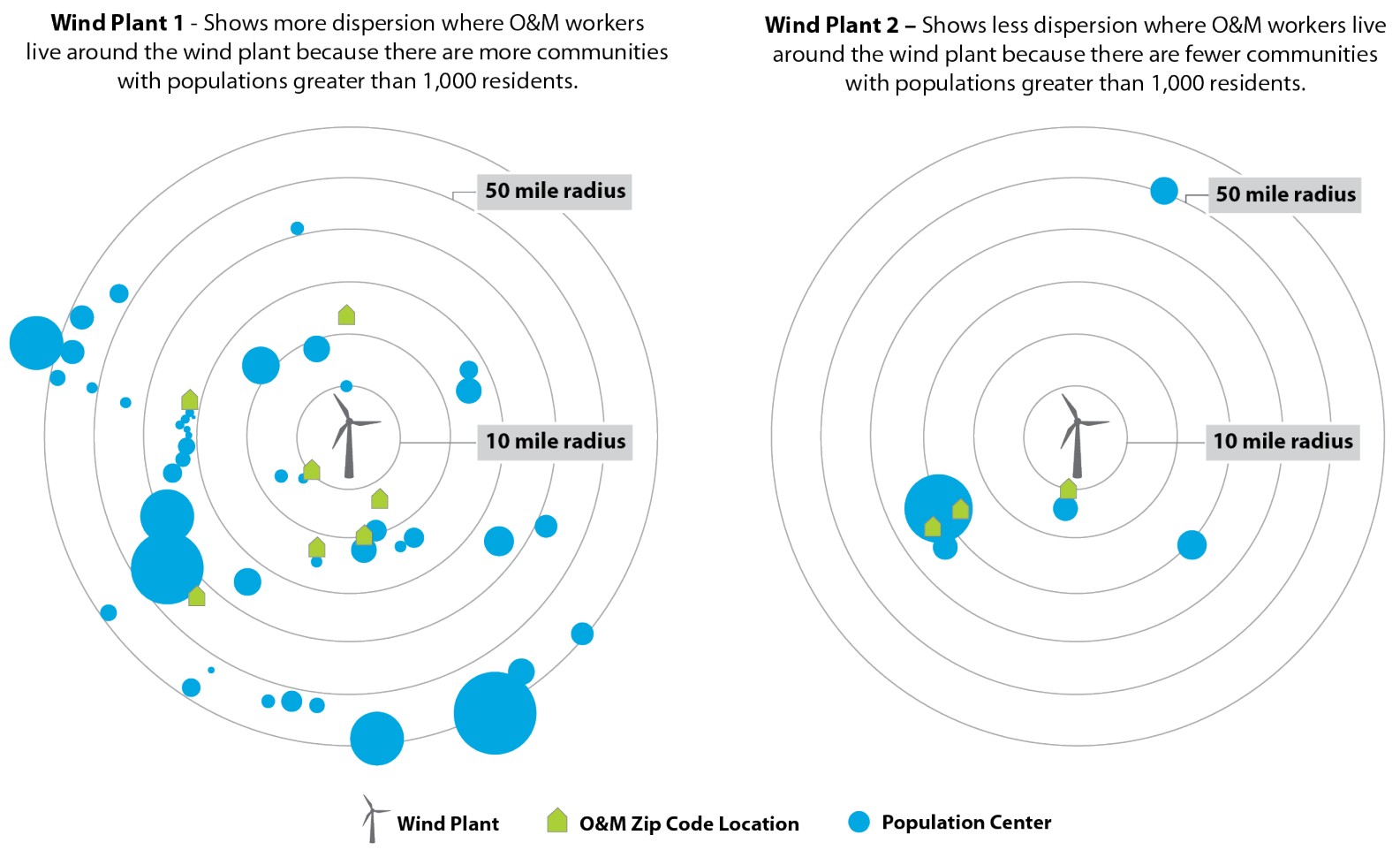

Figure 10. Population centers (blue) and location of where O\&M workers live (green) at two different wind plant locations (grey turbine) ${ }^{10}$

Workers at both wind power plant locations tend to live closer to communities near the wind plant that provide housing, retail, and amenities. At Wind Plant 1, there are 21 communities with a population greater than 1,000 residents within a 50-mile radius of the wind plant. Employee zip codes indicate workers are dispersed around the wind plant and are not centralized to one community. At Wind Plant 2, there are six communities with a population greater than 1,000 residents within a 50-mile radius of the wind plant, with four of the communities clustered less than a few miles apart from each other. In the region surrounding Wind Plant 2, employee zip codes are more centralized to single population centers.

\footnotetext{
${ }^{8}$ Only two of the six wind plants whose employees completed the survey could be mapped to the wind plant location. The remaining wind plants requested their employees' zip codes remain confidential.

${ }^{9}$ Location of wind plants are confidential to maintain anonymity in the data sets.

${ }^{10}$ Distance was measured in linear miles away from the wind plant. Driving distances are not represented in this graphic and may be impacted by roads and topography.
} 
Where a worker lives in relation to the wind plant has economic considerations for those communities near the wind facility. Wind plants located near fewer population centers are more likely to have a higher presence of workers living in a centralized community and therefore, spending their earnings and in turn increasing the economic activity in a single community. Wind plants located near multiple communities will likely have their workers dispersed across multiple communities, spreading earning and economic activity across the region surrounding the wind plant.

\subsection{Employment Structures in the Community}

Diversification of employment structures has been a trend in the industry, as wind power plant operators have had to choose between hiring contracted O\&M workers or hiring in-house employees. Recent literature has described the strategic trade-offs between cost and value between full-wrap service contracts and self-provision of turbine O\&M (Wiser and Bolinger 2018). However, these different employment structures also have economic considerations for communities near the wind plant.

\subsubsection{In-House and Contracted}

In our efforts to quantify the economic impacts of the O\&M workforce on the surrounding communities, the employer survey response indicated a similar trend with a diverse set of O\&M service option choices. Although our sample size is not conclusive nor a representation of the industry as a whole, $55 \%$ of the participating wind facilities in our sample outsource their O\&M services, as shown in Figure 11.

Wind plant O\&M employment structures based on employer survey responses

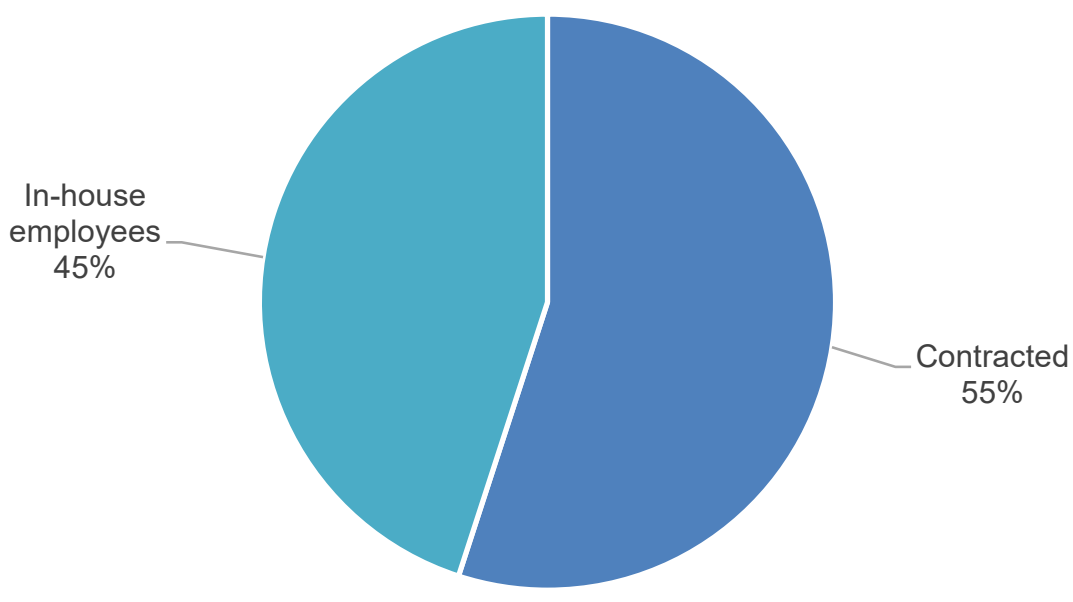

Figure 11. More operators responded that they utilize contracted labor structures rather than inhouse employees

The type of employment for wind facilities varies on a case-by-case basis. However, the employer sample represents most of the employment structures that would be utilized during the O\&M phase of a wind power plant. The data collected from the surveys reveal a variety of 
different employment types, which fall into two different categories: in-house employees and contracted workers. Within these two employment categories, there are four additional groupings, including full-time and part-time employment, which can be broken down further into permanent or temporary (seasonal) positions.

Employment positions for in-house workers include plant managers, resources directors, information technology technicians, service technicians, and administrators. Employment positions for contracted workers primarily include technicians, service managers, landscaping, janitorial services, and pest control.

Plant operators in our sample utilize in-house employees, contracted service crews, or a combination of both structures. All six plants within our sample size that contract their O\&M services also utilize in-house workers - these in-house workers vary between one and four permanent full-time employees. Of these plants that workshare in-house and contracted workers, the contracted workers conduct most of the significant maintenance on the turbines such as generator and blade replacement, whereas in-house employees typically include managerial positions.

\subsubsection{Community Impacts}

There are economic considerations for communities whether wind power plants hire in-house employees or contracted workers. Potential considerations include:

- Where are contract and in-house employees sourced?

- Are in-house workers more likely to be residents prior to working at the wind plant?

- Do contracted crews live in the communities where they work?

Every wind plant has varying employment structures and considerations. Therefore, we cannot conclusively answer these economic considerations for all communities across the United States. The data points collected represent high-level inferences for a limited sample of wind plants, employees, and communities.

The employee survey responses represent in-house and contracted workers. Four of the six wind plant employers distributed the employee survey only to their in-house workers, whereas the other two wind power plant operators distributed the employee survey to their in-house and contracted workers. In-house and contracted workers represent $57 \%$ and $43 \%$ of the sample size, respectively. 
In-house employee and contracted worker responses, when asked "where they live prior to and after employment" at the wind plant are shown in Figure 12.

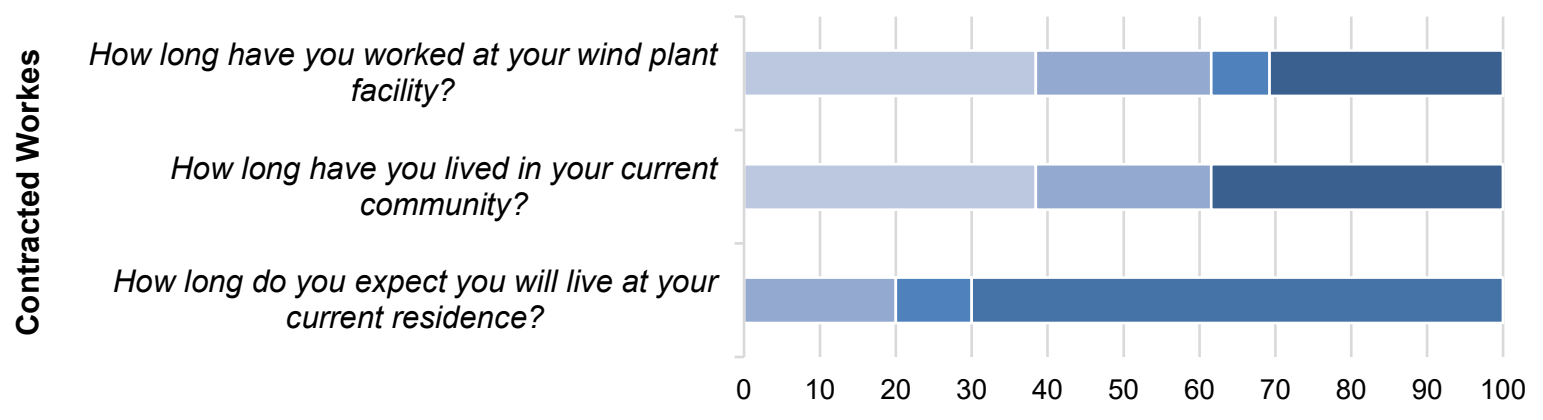

How long have you worked at your wind plant facility?

How long have you lived in your current community?

How long do you expect you will live at your current residence?

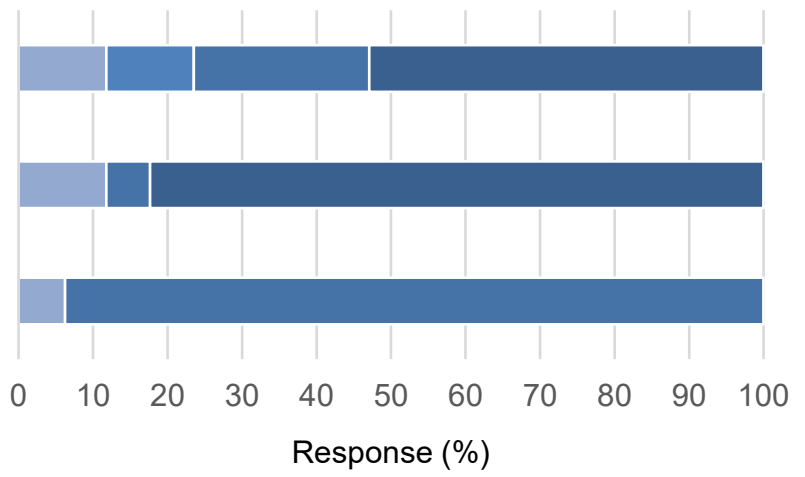

Less than 6 months

6 months to a year

More than a year up to 3 years

More than 3 years up to 5 years

More than 5 vears

Figure 12. In-house and contract worker responses to community-related questions

The length of time an employee has worked at a wind facility and lived in the community are correlated based on the data from our sample size. Contracted workers tend to be new residents in the community, more likely living less than a year in the region. However, the contracted workers also indicated they expect to live in the community up to 5 years. These data suggest that contract workers move into, live, and plan to live in the communities near the wind power plant, spending earnings in the local economies. 
In-house employees live longer in their communities prior to working at a wind facility. These data suggest that these wind plants have a more local workforce for their in-house employees, as opposed to contracted employees who moved into the area for O\&M work. Of all in-house employees, $50 \%$ responded to the question of "what are the primary reasons you live in your current community..." with the response that they or a close family member grew up there (Figure 13). The most common contract worker response when asked the same question, was they "like the community in general," which may indicate these workers have less of a connection to the community prior to working for the wind plant. Other factors such as distance to work, cost of living, and amenities, collectively are nearly aligned with both in-house and contracted workers, many of whom indicated they live and work in similar locations.

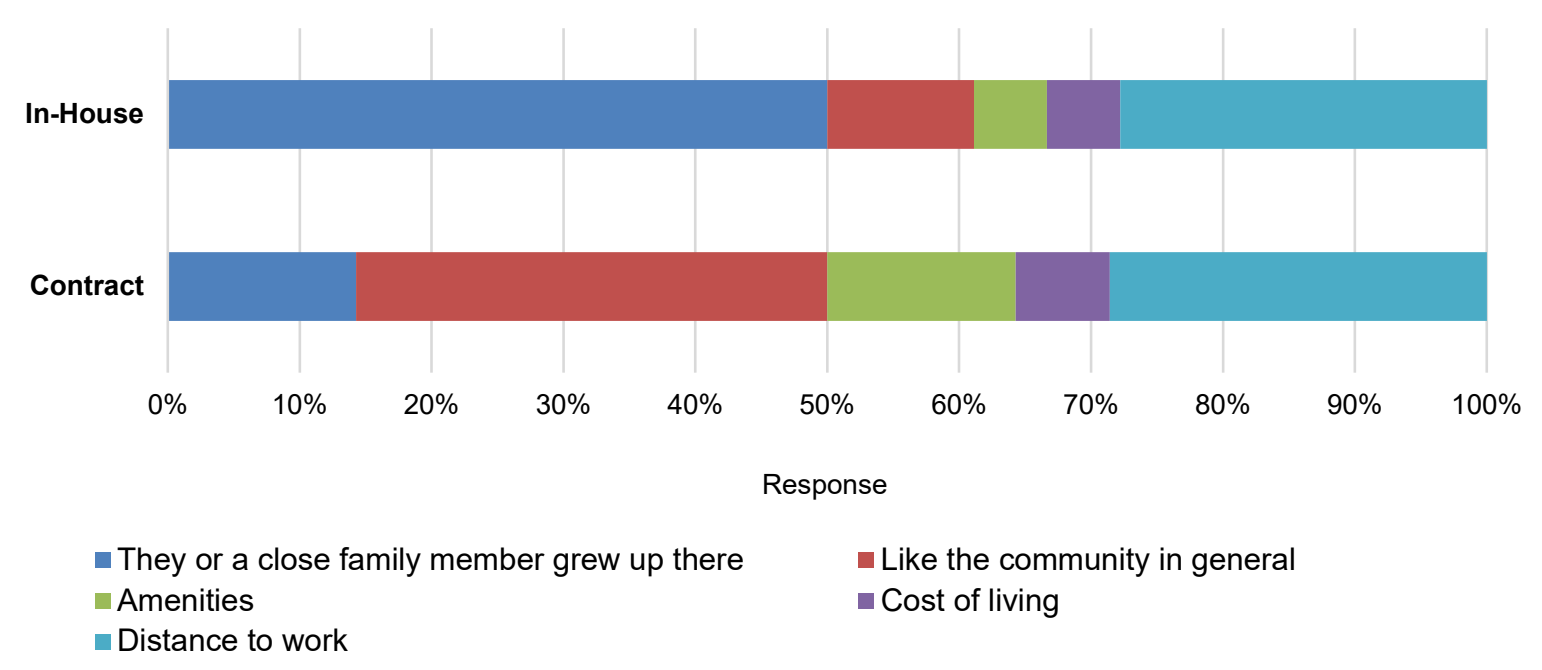

Figure 13. Reasons for choosing residence location

In our surveying, we were not able to quantify the economic differences between in-house employment with contracted service crews; we only obtained qualitative insights. It is unclear how each employment structure impacts the surrounding community's economy. Many additional answers to questions and new insights are needed to gain this understanding:

- Are contracted crews serving clustered power plants in the same region?

- What are the economic considerations of each employment structure?

- Need additional data from employers and employees to provide additional insights.

This is discussed in greater detail in Section 9 of this report. 


\section{Plant Workforce Characteristics}

The characteristics of employees at wind power plants give insight into the population most directly involved in the wind industry within affected communities. These highlighted characteristics from the employee survey put survey responses in context. For example, expenditure habits may be affected by salary level or occupation.

Employer survey responses offer more detail about workers not covered within the employee surveys. While no janitorial, landscaping, or pest control staff, nor any seasonal workers responded to the employee survey, some insights were provided at the employer level, but not enough to provide information within this report.

As mentioned earlier, throughout this report, the term "contracted worker" is used to reference part-time or full-time employees who service turbines and conduct O\&M responsibilities, including managers and service technicians. This phrase is not used to represent contracted workers, such as janitorial staff, landscaping, and pest control.

Plant characteristics provide further context from industrywide employment estimates. Different regions contain wind power plants of varying characteristics, such as geography, age of plant, and rated capacity, which can influence different hiring requirements and needs. BW Research merged employer survey data with EIA data using a proprietary model to develop industrywide employment estimates based on these plant characteristics. As previously mentioned, this model could only provide quantitative insights. Qualitative questions included in the survey, such as "does your wind farm provide any additional support to the community...?" are inherently subjective and could not be expanded to reflect the industry as a whole.

\subsection{Wind-Industry-Level Characteristics}

The employment data collected from the 11 wind power plants that participated in the employer survey were merged with 11 additional wind plants from the EIA Annual Energy Outlook database (EIA 2019b), which were selected because of their reported public O\&M employment data. By merging the 22 wind plants, we achieved a full geographical representation, with wind plants representing all four of the U.S. Census Bureau regions.

The original 11 wind facilities, identified from NREL's original database of 46 plants, include:

- Amazon Wind Farm U.S. East Project (South)

- Beech Ridge Project (South)

- El Cabo Project (West)

- Glenrock Wind Project (West)

- Horse Butte (West)

- Manzana Winds (West)

- Twin Buttes II (West)

- Confidential Plant 1 (West)

- Confidential Plant 2 (West)

- Confidential Plant 3 (West)

- Confidential Plant 4 (West). 
The 11 additional wind facilities that reported public O\&M employment data from the EIA Annual Energy Outlook database include:

- Blue Creek (Midwest)

- Capricorn Ridge (South)

- Flat Ridge 2 (Midwest)

- Fowler Ridge I (Midwest)

- Grande Prairie (Midwest)

- Lower Snake River (West)

- Maple Ridge (Northeast)

- Pioneer Prairie (Midwest)

- Roscoe (South)

- Santa Rita (South)

- Streator Cayuga Ridge South (Midwest).

BW Research created a data set by merging employment and characteristics of these 22 wind plants. To estimate the total number of O\&M workers required across the United States, this data set was modeled using information from every operating wind plant that was reported to the EIA, approximating the number of full-time employees for each wind plant. ${ }^{11}$ The results of this employment model calculate that active land-based wind plants in the United States require one full-time equivalent O\&M worker for every seven turbines. Within the EIA database, once a single turbine or a small group of turbines are registered, those turbines are then aggregated and issued a plant identification code by the EIA and recognized as a wind facility. These smaller, nonutility-scale wind facilities are included in BW Research's and NREL's calculations. According to the model, this equates to an O\&M workforce of 8,204 workers for the 94,971 MW of installed wind capacity, as of November 2019, the time at which BW Research conducted the analysis (EIA 2019a).

Average O\&M employment at U.S. wind plants varies because of characteristics such as geography, age of plant, rated capacity, and employment structures. Approximately $20 \%$ of U.S. wind power plants employ fewer than one permanent in-house worker, and almost a quarter (24\%) of all registered U.S. wind facilities include five or fewer wind turbines. Of the four geographic regions, the Midwest has the most, with 162 registered wind facilities of five or fewer turbines, followed by the West with 51 facilities, the Northeast with 42, and the South with 12. A more detailed breakdown of each region is shown in Table 2 .

About $70 \%$ of wind plants employ 9 or fewer O\&M workers, and about $30 \%$ employ 10 or more O\&M workers, which is indicative of the average rated capacity of a single wind plant in the United States at $85 \mathrm{MW}$ with an average expected employment of 9 workers (Figure 14). These O\&M worker estimates include technicians, managers, and administrative and support staff for each wind plant.

\footnotetext{
${ }^{11}$ Based on the installed wind capacity reported on Form EIA-860 as of September 2019.
} 


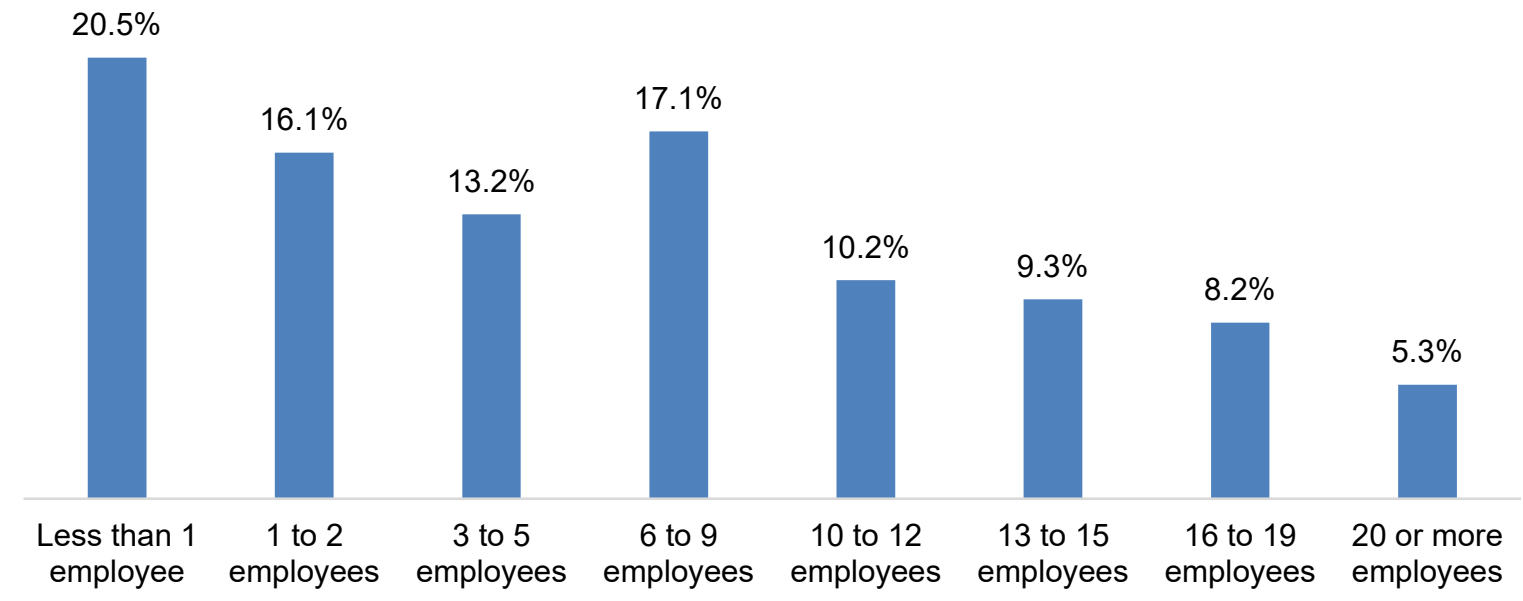

Figure 14. Average employment estimate across U.S. wind power plant fleet

\subsubsection{Geography}

The geographic location of a wind plant can impact O\&M employment characteristics in different ways. Land availability, population density, wind resource, and even regional market maturity are all geographically specific factors that will have an impact on O\&M workforce requirements.

Areas with greater land availability and lower population density tend to have wind power plants with higher nameplate capacities as well as other characteristics. Wind plants with higher nameplate capacities typically have more turbines, which often require a larger O\&M workforce.

Table 2 reveals how the four geographic regions, based on the U.S. Census, vary from one another. Population density, land area (in square miles), and population are used as benchmarks to quantify turbines and installed capacity per region. This table only includes counties in the United States that have at least one single registered turbine in the EIA database; counties with no turbines within all four geographic regions are not included in the table. ${ }^{12,13}$

\footnotetext{
${ }^{12}$ The U.S. Census Bureau provides a map of the census regions and census division definitions at https://www2.census.gov/geo/pdfs/maps-data/maps/reference/us_regdiv.pdf.

${ }_{13}$ Census regions were used rather than wind regions because employer surveys were combined with other data. These other data sources used census regions rather than wind regions, such as those in the "U.S. Wind Technologies Market Report."
} 
Table 2. Turbine and Installed Capacity Metrics for Population and Land Area

\begin{tabular}{|c|c|c|c|c|c|c|c|}
\hline & $\begin{array}{c}\text { Population } \\
\text { Density } \\
\text { (Sq. Miles) }\end{array}$ & $\begin{array}{l}\text { People per } \\
\text { Turbine }\end{array}$ & $\begin{array}{c}\text { People per } \\
1 \mathrm{MW} \\
\text { Installed } \\
\text { Capacity }\end{array}$ & $\begin{array}{c}\text { Land Area } \\
\text { per } \\
\text { Turbine } \\
\text { (Sq. Miles) }\end{array}$ & $\begin{array}{c}\text { Land Area } \\
\text { per } \\
\text { Capacity } \\
\text { (Sq. Miles) }\end{array}$ & $\begin{array}{c}\text { Turbines } \\
\text { by } \\
\text { Population } \\
\text { Density }\end{array}$ & $\begin{array}{c}\text { Installed } \\
\text { Capacity } \\
\text { by } \\
\text { Population } \\
\text { Density }\end{array}$ \\
\hline Northeast & 345.32 & $8,205.67$ & $4,240.88$ & 23.76 & 12.28 & 7.16 & 13.86 \\
\hline Midwest & 103.00 & 843.09 & 482.99 & 8.19 & 4.69 & 192.47 & 335.97 \\
\hline South & 89.10 & 516.97 & 274.51 & 5.80 & 3.08 & 198.90 & 374.57 \\
\hline West & 156.34 & $3,445.64$ & $2,697.54$ & 22.04 & 17.25 & 110.96 & 141.73 \\
\hline
\end{tabular}

When comparing the Northeast and South, the Northeast has the highest population density of people (general population) per single turbine as well as per $1 \mathrm{MW}$ of installed capacity. Furthermore, this region has the lowest number of turbines and installed capacity by population, supporting the claim that the Northeast is densely populated with less land suitable for wind development than the South. Conversely, the South has the lowest population density, fewest number of people per turbine, and the densest region regarding turbines and installed capacity per population density. These metrics further support how geography and population impact power plant characteristics within the four regions.

Of the 1,112 active wind facilities in the United States, almost a quarter of all registered facilities (267) have five or fewer turbines. The Northeast has the highest percentage of five or fewer turbines per facility, equating to $37 \%$, or 42 of the 113 wind plants in the Northeast. The Midwest has the second highest percentage of $36 \%$, or 162 of the 451 wind plants, and the West has $16 \%$, or 51 of the 319 registered facilities. The South only has about $5 \%$ of all wind facilities that include five or fewer wind facilities, or 12 of the 229 - this is indicative of the large availability of land in the region, resulting in larger-scale plants and, on average, more highcapacity machines.

Furthermore, of the four geographic regions, the Northeast has 36 registered wind plants - the fewest of the four regions - when compared to the Midwest (451), West (319), and South (229), respectively. These data support why geographic trends indicate that $79 \%$ of wind power plants across the Northeast employ five or fewer full-time O\&M employees. 


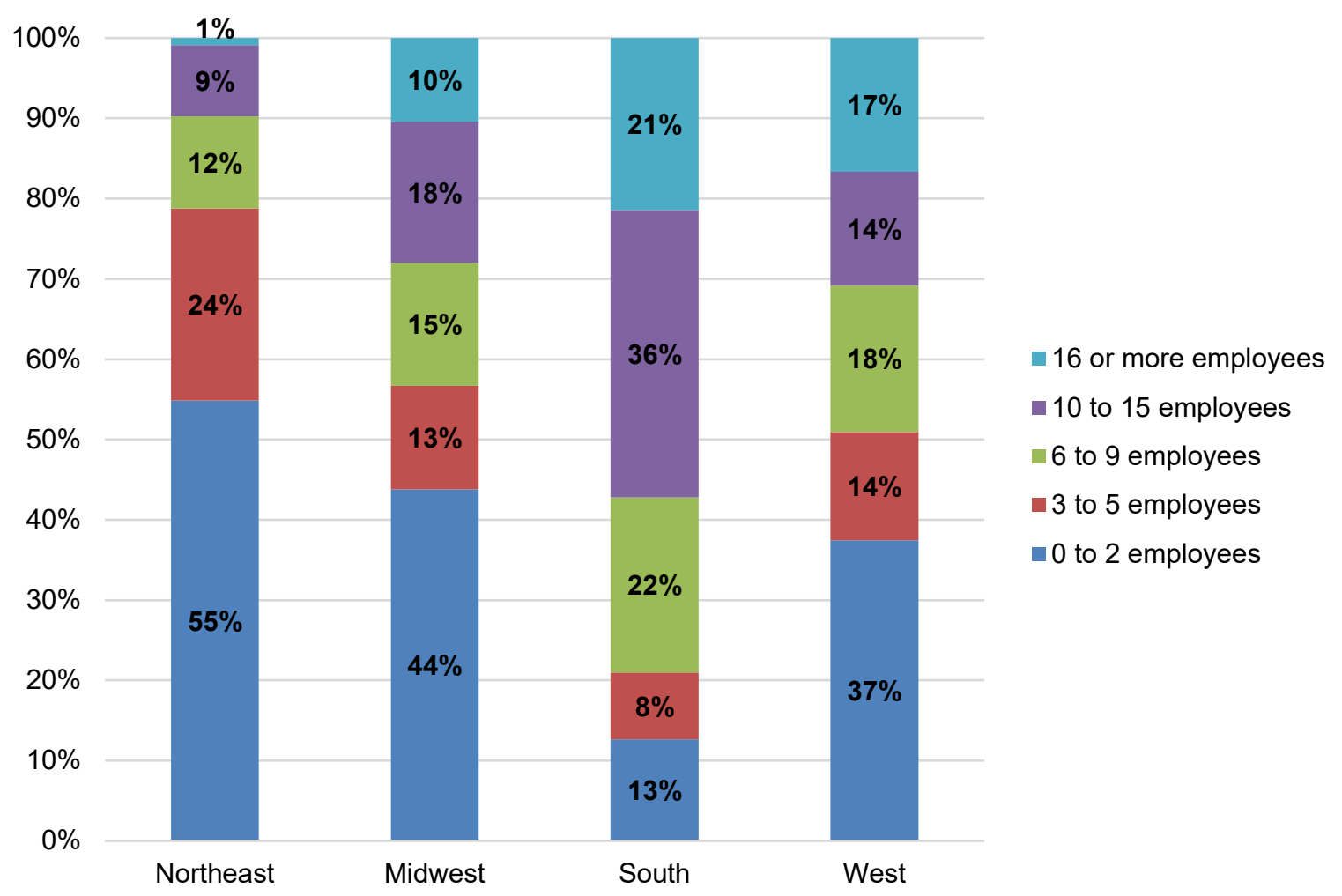

Figure 15. Average wind power plant employment based on census region

The Northeast includes states such as New York and Pennsylvania, where wind power plants have lower total nameplate capacities than the South and West geographic regions. In addition, the Northeast includes states such as Vermont and Maine, where turbines are installed with higher-rated capacities, resulting in fewer turbines to operate and maintain. ${ }^{14}$ The combination of wind facilities having a lower total facility nameplate capacity with fewer turbines at higherrated nameplate capacities, in addition to the Northeast having a higher population density (or less suitable land for wind development), results in fewer suitable areas for large-scale wind projects.

As shown in Figure 15, geographic trends indicate that $57 \%$ of wind plants across the Midwest employ five or fewer full-time O\&M employees, and $43 \%$ employ six or more employees. The Midwest collectively has the highest concentration of installed wind plant capacity in the United States, totaling $34,604 \mathrm{MW},{ }^{15}$ showing that more than $99 \%$ of the entire U.S. fleet of wind turbines is hosted in rural areas (American Wind Energy Association 2018). The varying degree of wind plant sizes, lower population density, predominantly rural regions, and access to excellent wind resources is indicative of the diversity of O\&M employment within the region.

\footnotetext{
${ }^{14}$ The U.S. Wind Turbine Database (https://eerscmap.usgs.gov/uswtdb/) provides publicly available data sets for total rated capacities for wind projects across the United States as well as turbine specifications.

${ }^{15}$ U.S. Energy Information Administration. Form EIA-860, September 2019.

https://www.eia.gov/electricity/data/eia860/.
} 
Over $57 \%$ of wind plants in the South, including Texas and Oklahoma, ${ }^{16}$ employ more than 10 employees on average in a region with a total installed capacity of 33,373 MW. Most notably, Texas and Oklahoma account for almost $97 \%$ of all installed capacity in the South, 24,187 MW and 8,071 MW, totaling 32,258 MW.

The West includes states with wind development such as California, Oregon, Washington, Utah, Idaho, Colorado, and Wyoming. The average employment of wind plants in this region is the most varied of any region, indicative of the many different geographic characteristics affecting deployment in these states.

\subsubsection{Age of Plant}

Older wind power plants require more workers to support the potential increase in maintenance as it ages, as compared to a newer wind plant that will likely have fewer turbines as a result of improvements in turbine technology that allow for greater electricity generation with fewer turbines.

Older plants on average have more turbines, 89 per plant, than wind plants commissioned in 2000 or after, averaging 50 turbines per plant. The average turbine rated nameplate capacity has increased since 1998-1999, as rotor diameter and hub height have increased (Wiser and Bolinger 2018). Wind plants that were commissioned prior to 2000 employ, on average, 13 or more workers, which is about double the workforce requirement to operate and maintain a wind plant commissioned in 2000 or after.

The average employment in the West follows a similar trend as the South, maintaining a higher employment on average (Figure 15). Table 3 shows average turbine capacity, percentage of plants commissioned before 2000, and plants commissioned in 2000 or earlier. The data show that the West has a higher employment average because the region has more wind facilities commissioned before 2000, and thus have more O\&M needs as a result of their age and a lower average nameplate capacity. There are 49 wind facilities commissioned before 2000 in the West, more than the Northeast (1), South (2), and the Midwest (14) regions.

Table 3. Wind Power Plant Characteristics by Age and Geographic Region

\begin{tabular}{|c|c|c|c|}
\hline & $\begin{array}{l}\text { Average Capacityl } \\
\text { Turbine (MW) }\end{array}$ & $\begin{array}{l}\text { Plants Commissioned } \\
\text { Before } 2000\end{array}$ & $\begin{array}{l}\text { Plants Commissioned } \\
\text { in } 2000 \text { or After }\end{array}$ \\
\hline Northeast & 1.93 & $0.9 \%$ & $99.1 \%$ \\
\hline Midwest & 1.75 & $3.1 \%$ & $96.9 \%$ \\
\hline South & 1.88 & $0.9 \%$ & $99.1 \%$ \\
\hline West & 1.28 & $15.4 \%$ & $84.6 \%$ \\
\hline
\end{tabular}

${ }^{16}$ U.S. Energy Information Administration. Form EIA-860, Sept 2019. https://www.eia.gov/electricity/data/eia860/. 
The average nameplate capacity of a single turbine commissioned before 2000 is $0.32 \mathrm{MW}$, accounting for 5,848 turbines. The average nameplate capacity of a single turbine commissioned in, or after, 2000 is $1.81 \mathrm{MW}$, accounting for 51,556 turbines. These numbers support that although the average nameplate capacity of a turbine commissioned in or after 2000 is substantially higher than a turbine commissioned before 2000 , a higher workforce is required to service older facilities because of the increased number of turbines rated at lower capacities.

\subsubsection{Rated Capacity}

As the capacity of a wind power plant increases, so do the O\&M workforce requirements. Turbine nameplate capacities vary depending on the region; factors that influence a region's average nameplate capacity include resource availability, land availability, and the age of a wind plant.

Figure 16 shows that wind plants with higher-rated capacities typically require more workers to operate and maintain the turbines.

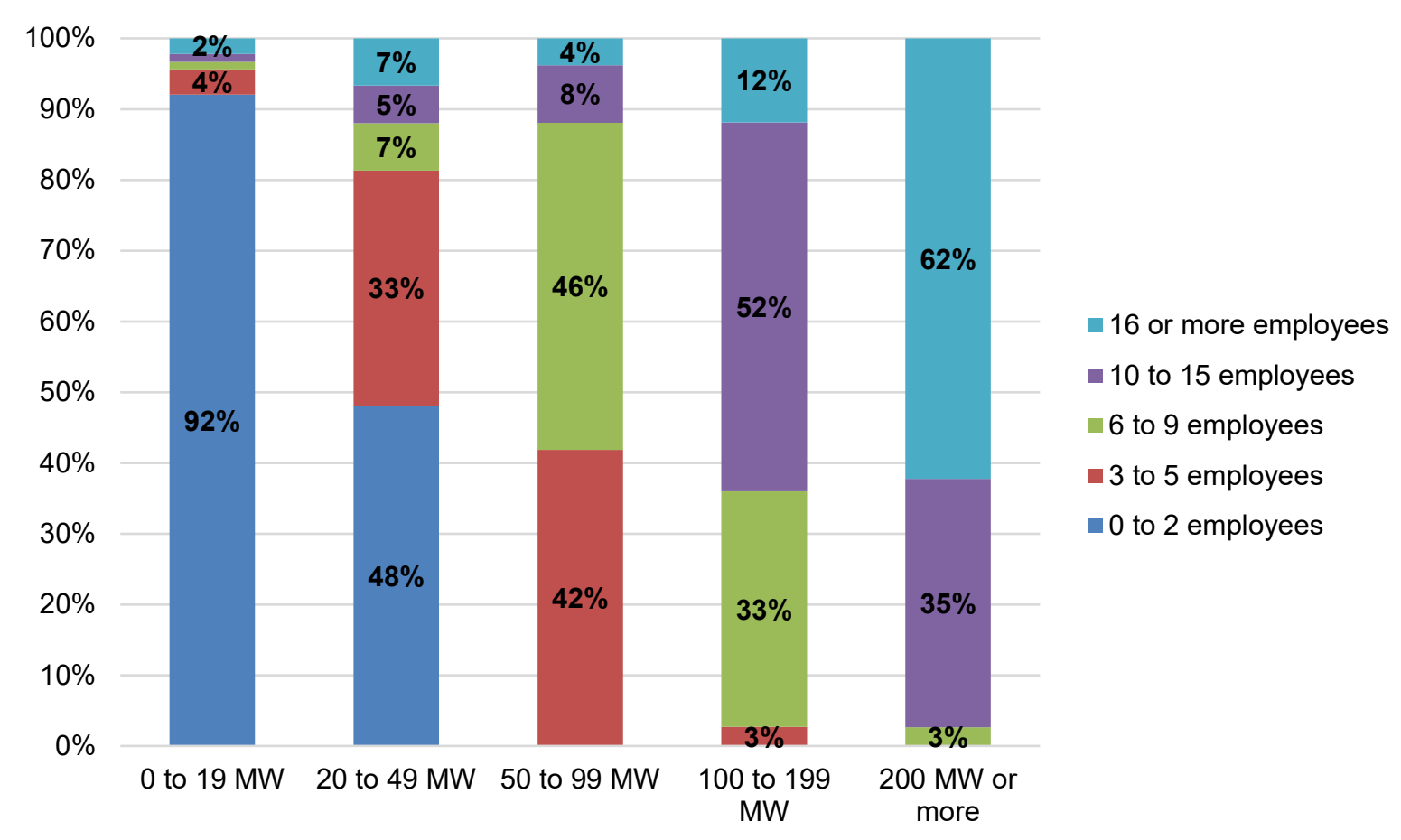

Figure 16. Average wind plant employment by capacity

These data show that as a wind plant's capacity increases, more employees are required to operate and maintain the facility. Wind plants with a maximum-rated capacity of $19 \mathrm{MW}$ seldom employ more than two employees. Wind plants with a rated capacity of more than $200 \mathrm{MW}$ are certain to employ, at a minimum, six full-time, permanent employees but on average employ more than 16 employees. 
The average nameplate capacity of a wind turbine in the Northeast - when accounting for the number of turbines in each of the four designated regions - reveals the highest average rated capacity of $1.93 \mathrm{MW}$ per machine, but the lowest average capacity per plant when compared to the other three regions. Although the South has the second highest average nameplate capacity per turbine of $1.88 \mathrm{MW}$, this region does have the highest average rated plant capacity of 145.73 MW.

Table 4 shows how geographic region, total rated regional capacity, number of turbines, average nameplate capacity per turbine, and average capacity per plant are all connected.

Table 4. Wind Power Plant Characteristics by Geography

\begin{tabular}{|c|c|c|c|c|}
\hline & $\begin{array}{c}\text { Total Rated } \\
\text { Capacity (MW) }\end{array}$ & $\begin{array}{c}\text { Number of } \\
\text { Turbines }\end{array}$ & $\begin{array}{c}\text { Average } \\
\text { Capacity/ Turbine } \\
\text { (MW) }\end{array}$ & $\begin{array}{c}\text { Average Capacity } \\
\text { per Plant }\end{array}$ \\
\hline Northeast & 4,785 & 2,473 & 1.93 & 42.35 \\
\hline Midwest & 34,604 & 19,824 & 1.75 & 76.73 \\
\hline South & 33,373 & 17,721 & 1.88 & 145.73 \\
\hline West & 22,208 & 17,386 & 1.28 & 69.62 \\
\hline
\end{tabular}

Typically, wind turbines with larger nameplate capacities will have similar O\&M requirements to turbines with lower-rated capacities, furthermore, technological innovations have increased turbine electricity generation capabilities; therefore, facilities with larger turbine nameplate capacities, such as in the Northeast, may require fewer O\&M workers per megawatt, despite their larger plant capacity.

The Midwest and South are expected to have the largest O\&M crews followed by the West, as a result of the higher number of turbines per region. Older wind plants also require more maintenance, which contributes to higher workforce needs per megawatt in regions with more plants commissioned prior to 2000, as is the case in the West region.

\subsection{Hiring Difficulty}

When plant operators were asked about hiring difficulties for their O\&M workforce, responses varied. Those plant operators who cited not having difficulty hiring mentioned that there is an excessive number of applicants qualified for the job, stating there are "very few [applicants] that we can turn away easily." Furthermore, some plant operators have not had a need to hire additional O\&M workers for at least the past 5 years.

In contrast, some respondents in the employer survey included hiring difficulty as a result of competing industries within the same region offering better salaries. Additional reasons for a shortage of job applicants result from remote wind facility locations, inadequate experience for the job position, unwillingness of workers' family to relocate, and salary.

These survey responses align with a recent land-based wind workforce analysis, in which $67 \%$ of industry has no difficulty finding qualified wind technicians, whereas $33 \%$ has some or great 
difficulty (Keyser and Tegen 2019). Furthermore, a disconnect between industry and qualified candidates exists across the wind industry, which may be a result of geography or finding better opportunities in other industries.

Wind operators could look to local high schools and community colleges to provide a skilled O\&M workforce. In many instances, before transitioning into the O\&M technician workforce, employees had lived and worked in the surrounding region prior to the commissioning of a new wind facility or transitioning into a role to support an existing wind plant. This employee trend highlights that a solution to bridging the wind workforce gap and mitigating wind O\&M hiring difficulty would be for the wind industry to support wind technician programs in regions where a high frequency of wind power plants exist, or where a wind workforce will be needed in future instances. 


\section{Extended Economic Community Impacts}

Communities can expect various forms of extended economic impacts from the existence of a nearby wind facility. There are two types of incoming revenue streams during the O\&M phase of a wind plant: tax-based and nontax-based.

Within the tax-based revenue bracket, the primary area in which wind plants spend money within local communities is on temporary subcontractors, indicated by $75 \%$ of employer survey respondents. Most of this subcontracting work was identified for general site maintenance and repairs but also includes landscaping, janitorial, and pest control services. Communities also receive tax revenue from wind plants sourcing parts, hardware, and additional equipment, such as with vehicle purchases through local car dealerships. ${ }^{17}$

Additional tax-based revenue streams that can be typically expected within the surrounding communities are those established during the development phase of a wind facility, prior to construction. These additional revenues streams can include property tax payments, internal revenue bonds, as well as restructured tax payments. The amount of these tax-based revenue streams depend on various factors including, but not limited to, wind resource availability, region, siting authority (state versus county), specific wind policies, access to transmission infrastructure, and the electricity market in which the facility is sited.

Expected nontax-based revenue streams include payment in lieu of taxes, host community agreements, strategic investment payments, royalty payments to landowners, and other revenues that can be difficult to quantify, such as developer community investments (good neighbor agreements).

The impact of wind plants, however, extends beyond quantitative economic metrics such as jobs, tax expenditures, local spending on goods and services, and land lease payments. Often, the largest impact of wind O\&M comes from spending that is not required to operate the wind plant (Munday et al. 2011). These types of extended community impacts are often known as "developer community investments" or "good neighbor agreements."

Employers were asked about this type of spending in communities and other community involvement. All responded with some extended activities, although these activities varied. Responses included:

- Sponsorship of local youth sports teams

- Contributions for volunteer public services such as fire departments

- Charitable donations to local organizations including schools, 4-H clubs, homeless shelters

- Investments in communities through funding infrastructure projects such as sidewalks and multiuse recreational paths

- Improvements in surrounding community road infrastructure (on public and private land)

\footnotetext{
${ }^{17}$ There were not enough responses to disclose percentages for these responses individually while maintaining confidentiality.
} 
- Volunteer work

- Formation of curriculum to support wind technician training programs. 


\section{Modeled Wind Plant Economic Community Impacts}

Wind power plant spending in communities supports local jobs and other economic impacts beyond the number of workers the wind plant employs. This greater local supply chain and local expenditure of both O\&M workers and supply chain workers must be considered. The level of these impacts will depend both on the availability of goods and services within the community and the extent to which local businesses will utilize these resources.

The IMPLAN ${ }^{18}$ model can be used to estimate these impacts. IMPLAN is an input-output model that captures the linkages between businesses and households through spending patterns. Within a region, this model captures sales and purchases made by households, governments, and businesses. Every local purchase made by one of these groups is a sale by another. When a business makes a purchase, for example, they purchase it from another business, which is a sale to that business.

Parameterizing the IMPLAN model requires some information about the number of employees or regional spending of the employer. This number is applied as demand for outputs produced by the wind electricity generation sector, which is included in the IMPLAN model.

BW Research estimated these impacts using employment data obtained from employer surveys. These surveyed wind facilities are case studies that only reflect a range from the specific plants sampled from this study; impacts do not represent the wind industry as a whole.

This analysis produces four impact metrics: jobs, earnings, value-added, and output.

- Jobs are defined as FTE, which means one person working full time for 1 year. A worker who only works full time for 6 months, for example, would be 0.5 FTE.

- Earnings are total payments for a worker. To an employer, earnings are total labor expenditures. These include retirement payments and other benefits.

- Value-added is the equivalent of the gross domestic product. It comprises earnings, property-type income, and taxes. Property-type income, also known as gross operating surplus, comprises business earnings such as profits.

- Output, also known as gross output, is the total amount of money exchanged. At a business level, it can be thought of as revenue. It is not a metric of profitability or the economic contribution of businesses and workers.

Impacts are categorized as direct, indirect, and induced. These categories capture employment and associated economic activity of the wind plant itself, as well as what is often known as the economic multiplier "ripple effect" that it has in the county or counties where it is located. These impacts are captured within three categories:

- Direct impacts are the O\&M employees and the associated earnings and value-added and gross output associated with these workers. This impact, in terms of jobs, is the number of workers employed at a wind plant — in this instance, an O\&M employee such as a

\footnotetext{
${ }^{18}$ More information about IMPLAN can be found at implan.com.
} 
service technician or facilities manager. The direct impact is how the model was parameterized with results from the employer surveys.

- Indirect impacts capture the local supply chain within the county where the wind plant is located. These could include, for example, local business services, such as landscaping, accounting, or hardware, or even a worker employed by a facility that manufactures wind turbine components. These impacts also include contractors such as cleaning crews or those that perform landscaping. ${ }^{19}$

- Induced impacts accrue as a result of employees captured under direct and indirect impacts, spending money within the county or counties in which the wind plant is operating. An example of an induced impact could be a restaurant hiring additional staff or receiving additional revenue from in-house or contracted O\&M workers purchasing lunch at a restaurant.

Because a model is used to estimate indirect and induced impacts, these impacts are generalized. Induced impacts from direct and indirect worker expenditures are not influenced by employee responses about where they spend their paychecks.

Table 5 shows average impacts from the NREL sample of 11 plants, per megawatt of capacity as well as impacts per turbine and includes a range of indirect and induced impacts. ${ }^{20,21}$ This range is not given for direct impacts to protect the confidentiality of respondents. Additionally, the following data show the impacts within the counties in which these plants are located and is not necessarily a representation of the national average.

Table 5. Average Estimated O\&M County-Level Impacts of Wind Plants Sampled

\begin{tabular}{|l|l|l|}
\hline & $\begin{array}{l}\text { Average Jobs (FTE) per } \\
\text { Megawatt }\end{array}$ & Average Jobs (FTE) per Turbine \\
\hline Direct & 0.11 & 0.20 \\
\hline Indirect & $0.33(0.07-0.73)$ & $0.57(0.15-1.10)$ \\
\hline Induced & $0.06(0-0.14)$ & $0.11(0.01-0.22)$ \\
\hline
\end{tabular}

On average, the wind plant operators who were interviewed in this study employed 0.11 FTE per megawatt and 0.20 FTE per turbine (Table 5). Variations in indirect and induced impacts, as shown in Figure 17, are driven by a number of factors, including wages and the size and interconnectedness of local economics; in this case, defined as the counties in which the plants are located. Higher wages - both by the plants themselves and their greater local supply chainstranslate to more expenditures made by workers. Larger economies tend to have more options to

\footnotetext{
${ }^{19}$ Contractors are not a part of the direct impact because they are not employed by the wind operator itself. They are employed by a third-party business that the operator pays and are therefore considered a part of the basket of inputs purchased by the operator to do business.

${ }^{20}$ Impacts of individual plants and/or a range of estimates are not included to protect confidentiality.

${ }^{21}$ The number of direct jobs per megawatt differs from the total number of O\&M jobs per total installed capacity in the United States because the survey respondents are a subset of U.S. plants.
} 
develop local supply chains, although highly linked supply chains can exist within smaller economies based on purchasing decisions.

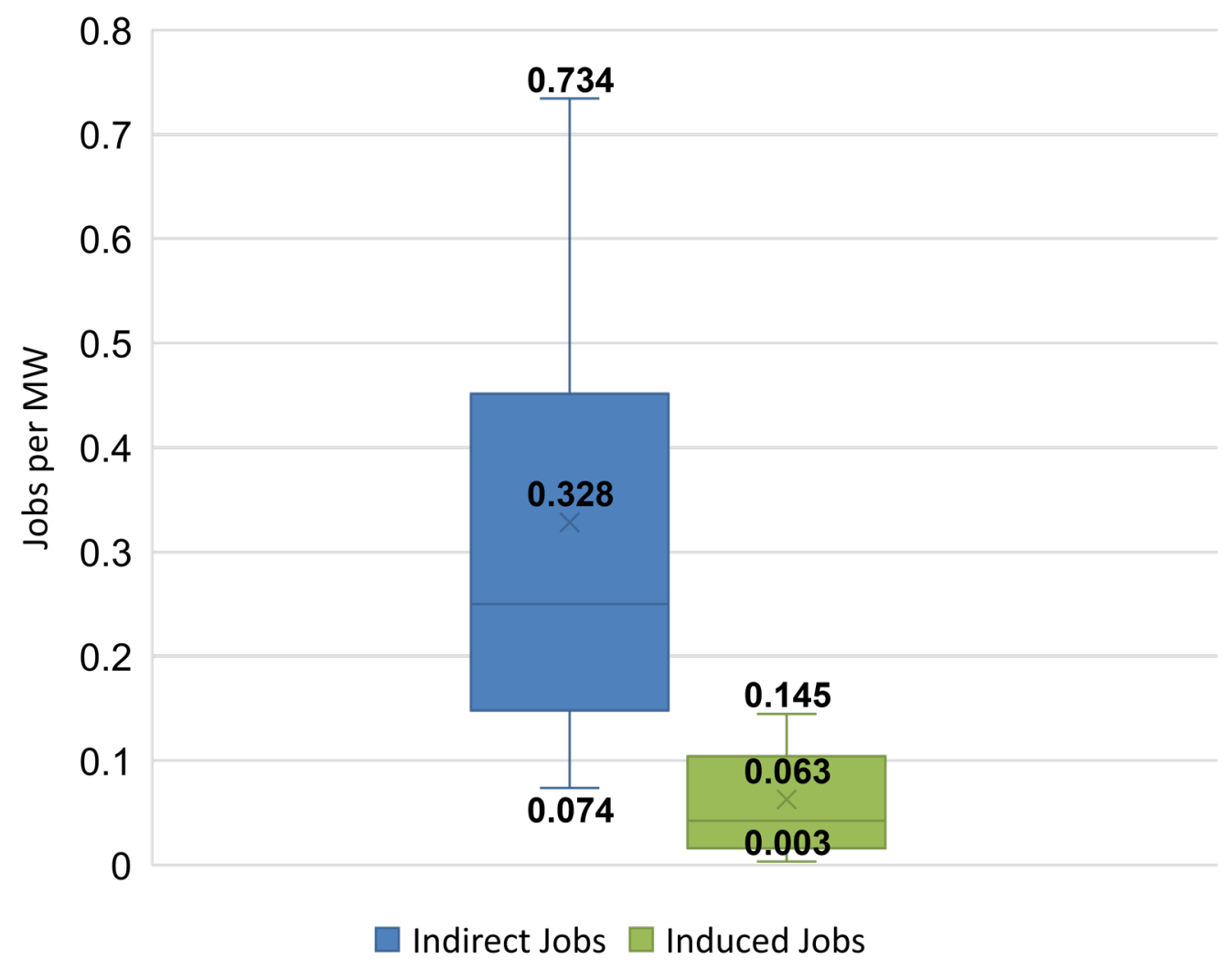

Figure 17. The average and range of indirect and induced jobs in the sample

The overall contribution of power plants to local economies, value-added, is also driven by the compensation of direct, indirect, and induced workers. Part of the value of these plants and other affected industries is additional tax revenue, which is also a component of value-added. As shown in Table 6 , on average, producers pay $\$ 18,000$ in taxes per megawatt of capacity and $\$ 30,000$ per turbine to their local state and federal government. Ranges depend on taxing structures and rates. The value-added impact averages $\$ 105,000$ per megawatt and $\$ 184,000$ per turbine.

Table 6. Value-Added Gross Domestic Product and Taxes from Wind Plant O\&M ${ }^{22}$

\begin{tabular}{|l|l|l|l|l|}
\hline Average & \multicolumn{2}{c}{$\begin{array}{l}\text { Value-Added/MW } \\
\text { Value- } \\
\text { Added/Turbine }\end{array}$} & \multicolumn{1}{c}{ Taxes/MW } & Taxes/Turbine \\
\hline Range & $\$ 105,000$ & $\$ 184,000$ & $\$ 18,000$ & $\$ 30,000$ \\
\hline & $\begin{array}{l}\$ 26,000- \\
\$ 221,000\end{array}$ & $\begin{array}{l}\$ 42,000- \\
\$ 464,000\end{array}$ & $\$ 5,000-\$ 39,000$ & $\$ 10,000-\$ 58,000$ \\
\hline
\end{tabular}

\footnotetext{
${ }^{22}$ Based on case studies developed from the 11 wind power plants surveyed. The ranges shown in the table are the minimum and maximum for communities near these wind plants.
} 
In all cases, the largest impacts are indirect, whereas the smallest are induced. This shows that the biggest quantifiable impacts from wind plants are a result of local supply chains and not necessarily spending by the wind plant or supply chain workforce. These impacts are at the county level and given that respondents generally indicated commutes greater than 30 minutes, these impacts could imply that the workforce does not reside in the county or group of counties where a plant is located.

These economic impacts also reflect an industry with high expenditures on inputs relative to its O\&M workforce. At a local level, examples of these expenditures include small parts, hardware stores, vehicle dealerships, and contracted services such as landscaping, cleaning, and maintenance and repair services. If a local community can offer these types of resources, they can expect to have some type of increased economic impact, compared to a local economy that does not offer such resources.

The tax structures vary from locality to locality, particularly for wind generation, as it differs from the fossil generation for which the codes were previously written. While not a complete set of structures, some governments tax wind power plants based on the electricity generated. Other government structures tax wind facilities based on the cost of the wind plant. Table 7 shows the range of payments per megawatt of electricity generated, which depends on location and wind resource. Table 8 shows payments per tower among respondents. In all cases, the highest tax payments are to the federal government. ${ }^{23}$ Taxes per turbine are greater than taxes per megawatt generated.

Table 7. Direct Tax Payments per Megawatt of Capacity

\begin{tabular}{|c|c|c|c|}
\hline & Federal & State & Local \\
\hline Minimum & $\$ 1,300$ & $\$ 900$ & $\$ 90$ \\
\hline Average & $\$ 5,000$ & $\$ 2,000$ & $\$ 2,000$ \\
\hline Maximum & $\$ 9,000$ & $\$ 5,000$ & $\$ 7,000$ \\
\hline
\end{tabular}

Table 8. Direct Tax Payments per Tower

\begin{tabular}{|c|c|c|c|}
\hline & Federal & State & Local \\
\hline Minimum & $\$ 2,900$ & $\$ 1,800$ & $\$ 200$ \\
\hline Average & $\$ 9,000$ & $\$ 5,000$ & $\$ 3,000$ \\
\hline Maximum & $\$ 20,000$ & $\$ 8,000$ & $\$ 11,000$ \\
\hline
\end{tabular}

${ }^{23}$ These are all tax payments to the federal government, including taxes such as social security and taxes on profits. 


\section{Future Research Opportunities}

Although this study provides a range of information about wind power plant operators and their in-house employees, further areas of study could provide additional insight into how wind O\&M impacts surrounding communities.

Only operators and their employees were surveyed for this study, not local businesses or governments. Stefek et al. (2019) provides some of these community insights during the construction of the Rush Creek wind plant in Colorado, but this research could be expanded to the O\&M phase of a diverse set of plants, all of which have varying characteristics.

The framework created in this report could also be replicated for a study researching the economic impacts of a manufacturing facility and its regional economic impact on the surrounding communities.

Another question that arose from this research was understanding housing availability in proximity to a wind power plant. In one example case study in our research, the zip codes provided by employees differ from the zip code of the wind plant's location. This is particularly relevant for workers who cited proximity to the wind plant as a reason for where they chose to live, yet workers also cited commutes longer than 30 minutes, as shown in Figure 8. Further researching this topic could offer insight into how housing availability could impact local communities.

Furthermore, in our efforts to quantify the economic impacts of the O\&M phase of a wind plant, we encountered a trend in which some wind facilities utilized a contracted service crew, rather than provided an in-house workforce for a wind facility's O\&M requirements. Of the 11 wind power plants surveyed from the NREL database, six utilized contracted workers to some capacity, and five of these six facilities workshare between both in-house and contracted workers.

In our research, we were not able to quantify the economic impacts on a local community between an O\&M workforce that is sourced in-house and that of an outsourced, contracted service crew. There are many variable economic factors associated with this research opportunity, including what the workshare might look like at a wind facility and what the economic outcomes on the local community might be. For example, understanding the economic impacts of the O\&M phase of wind plants will all have different economic outcomes, depending on their workforce, whether operators source only in-house workers, contracted workers, or shared employment between in-house employees and a service crew. These economic impacts are unknown and offer a research opportunity to quantify the differences between the various wind O\&M employment structures.

The economic differences between a wind facility creating "new" O\&M jobs requiring new FTE-equivalent positions, and a wind facility providing jobs that are to be supported by an existing regional service crew will have distinctive economic differences on the local surrounding communities. Understanding these economic differences is particularly important because the impacts to the surrounding communities could have a different result than what local community representatives or stakeholders were expecting from the development of a new wind plant. 
A complementary research opportunity would be to identify how wind power plant clustering might also impact the workforce requirements for existing and new wind plants. In our data set, of the wind facilities that source their O\&M services through contracted workers, all the facilities in some capacity are clustered with at least one other utility-scale wind plant. Although our sample size is not conclusive, this does present a research opportunity to understand how wind plant clustering and other factors may impact wind workforce opportunities and what impacts these can have on the surrounding communities.

It is unknown how wind plant clustering might impact the geographic range of contracted O\&M service crews and the associated economic impacts of this O\&M employment model. Studying the economic impacts of a contracted crew that, for example, rotates between servicing wind plants within a 50-mile radius or a crew that services multiple wind plants in multiple states could cause considerably different economic impacts. This has not yet been studied and offers an opportunity much like the previously aforementioned subjects.

It is also likely that there are economies of scale associated with larger plants or plants that are clustered together. While this study did gather a basic level of information about the differences in employment levels, a larger sample is needed to make this information more statistically robust. 


\section{Conclusion}

Rural communities are impacted economically - to varying degrees - by the influx of workers to support the O\&M needs of an operating wind power plant. Previously, the economic impacts of how an O\&M workforce has interacted with the surrounding communities near a wind facility were unknown; however, this report has begun quantifying these impacts. As previously mentioned, about $99 \%$ of all wind facilities are sited in rural areas in the United States (American Wind Energy Association 2018). Understanding how an O\&M workforce might affect the surrounding regions is important, as these rural areas are the most heavily impacted by the O\&M phase of an operating wind plant. Often, O\&M workers are located in or around these communities, helping stimulate the local economy.

Wind power plants and their employee workforce affect the local and surrounding communities in several qualitative and quantitative ways. These impacts vary from companies' and workers' spending at local businesses, to the role that these companies and workers play in the quality of life within the communities. Furthermore, the workforce needs of wind plants vary because of a number of factors including capacity, number of turbines, age, and geographic location.

The average income for wind technicians is $\$ 55,000$ annually while managers and supervisors earn $\$ 88,000$ annually on average. Survey results indicate that almost $77 \%$ of O\&M technicians indicated that they "strongly agreed" they expect to maintain a career path within the industry over the next 5 years, whereas 13\% "somewhat agreed," and no respondents disagreed. In addition, once a new facility is commissioned, workers supporting these O\&M tasks typically spend their money where they work and live. With respect to worker spending habits, $80 \%$ of workers "agree" they spend money in the community they work, and $87 \%$ indicate they "somewhat" or "strongly agreed" to spending most of their money where they live. Pairing employee salaries and spending habits with career path expectations provides valuable information to county commissioners and other key decision makers. These data support the notion that an O\&M labor force is a source of revenue in nearby communities, helping stimulate local rural economies. As a result, these local communities can expect some level of increase in economic growth once a new wind facility is operational, with O\&M workers spending most of their wages in the surrounding regions, likely for the duration of an operating wind power plant's life span, which can last between 20 and 25 years (Ray 2017).

To add further context in addition to pairing employee salaries and spending habits, as has been highlighted in this report, of the 11 wind plants that participated in the BW Research survey, for every $1 \mathrm{MW}$ of installed capacity, a local community can expect 0.11 FTE positions; or if a wind facility were rated for $100 \mathrm{MW}$, approximately 11 FTEs would be required to service the plant. ${ }^{24}$ Additionally, on average, the local communities can expect, for every $1 \mathrm{MW}$ on average, 0.33 indirect and 0.06 induced FTE positions. Although these data represent the 11 sampled wind plants, and only shows the impacts within the counties in which these plants are located, these

\footnotetext{
${ }^{24}$ Wind plant employment is not necessarily a linear curve. For example, a 600-MW wind plant will likely not employ 60 workers. Therefore, larger wind plant sizes have some economies of scale causing lower employment increases at larger plant sizes.
} 
FTE metrics provide a more detailed level of understanding as to how a wind facility, during its O\&M phase, might impact the local surrounding communities.

However, for the entire U.S. fleet of land-based wind power plants, we estimate that one fulltime equivalent O\&M worker is required for every seven turbines, or 0.086 FTE per $1 \mathrm{MW}$ of installed capacity. This equates to 8,204 O\&M-specific workers for the 94,971 MW of operational wind capacity in the United States as of November 2019.

Land-based wind energy has grown at an annual rate of $13 \%$, requiring an increased need for an additional workforce to support associated O\&M requirements (EIA 2019a). The wind industry employed 111,166 workers in 2018 across all industry sectors. The labor force in the O\&M sector is not evenly dispersed geographically in the United States. A higher concentration of the O\&M workforce is located in more wind-plant-dense areas.

A wind plant's various characteristics, such as geography, number of turbines, rated capacity, and commissioning date, play a role in the workforce requirements for a single facility. In regions with less population density and greater land availability, wind facilities with higher nameplate capacities are more prevalent. These wind facilities tend to have more turbines, which require a larger O\&M workforce because of the increased servicing needs. As a wind plant's rated capacity increases, so too do the servicing requirements for the facility. For example, a wind plant with a rated capacity of $100 \mathrm{MW}$ will require about three times the workforce than a wind facility rated at $30 \mathrm{MW}$.

The commissioning date of a wind facility also impacts workforce needs. In this report, 2000 was identified as a milestone year. Wind power plants commissioned before 2000 require a larger workforce than those commissioned in or after 2000. This is a result of technological advancements; turbines commissioned before 2000, on average, have a lower turbine nameplate capacity of $0.32 \mathrm{MW}$, compared to a turbine installed in or after 2000 with an average nameplate of 1.8 MW. Therefore, wind plants commissioned before 2000 require a larger O\&M workforce, on average 13 more O\&M workers than a wind facility commissioned after 2000.

The output from this report supports NREL's existing Jobs and Economic Development Impact model, ${ }^{25}$ which helps estimate the direct, indirect, and induced economic impacts of constructing and operating power generation on the state and local level. The information collected from wind plant O\&M characteristics and employee spending patterns is used to update the model, increasing the accuracy of available modeling capabilities to offer a more accurate resource for stakeholders.

Additionally, there are extended impacts from which the local community benefits that reach beyond any quantifiable measures. Often, during the O\&M phase of the wind plant, developers or power plant operators will provide "developer community investments" or "good neighbor agreements' as a gesture of good faith. These benefits include, but are not limited to, sponsorships of local sports teams, charitable donations, volunteer work, and support of local wind technician programs. These types of benefits, although not often included in any economic

\footnotetext{
${ }^{25}$ For more information, see: https://www.nrel.gov/analysis/jedi/.
} 
metrics, are additional benefits that community decision makers should consider in their assessments of ways in which the operating phase of a wind facility could impact the local rural community.

By quantifying these economic impacts, we hope this information will allow communities to better prepare for anticipated economic activity and make informed decisions to maximize potential economic impacts, such as with developing necessary infrastructure that can stimulate the local economy by supporting the O\&M needs of a wind power plant. Prior to this report, insights such as identifying a wind workforce's spending habits within a region were largely unknown. Pairing this information with an understanding of the operational life span of a wind facility, for example, can help local community representatives gauge how to prepare and sustain their rural community.

Unanswered questions remain, however, about elaborating on the impact of contracted workers and outsourcing in wind power plant operations and community economic development. Additionally, changes in technology could impact future workforce needs. Improvements in wind technology will allow the industry to use larger generators and fewer turbines, allowing for improvements in worker productivity and resulting in fewer O\&M workforce needs per wind facility. 


\section{References}

American Wind Energy Association. 2018. U.S. Wind Industry Annual Market Report. https://www.awea.org/resources/publications-and-reports/market-reports/2018-u-s-windindustry-market-reports (page 111).

Brown, Jason P., John Pender, Ryan Wiser, Eric Lantz, and Ben Hoen. 2012. "Ex post analysis of economic impacts from wind power development in U.S. counties." Publications from USDAARS/ UNL Faculty. https://digitalcommons.unl.edu/usdaarsfacpub/1144.

Halvatzis, Sandra, and David Keyser. 2013. Estimated Economic Impacts of Utility Scale Wind Power in Iowa. Golden, CO: National Renewable Energy Laboratory. NREL/TP-6A20-53187. https://www.nrel.gov/docs/fy14osti/53187.pdf.

Keyser, David, and Suzanne Tegen. 2019. The Wind Energy Workforce in the United States: Training, Hiring, and Future Needs. Golden, CO: National Renewable Energy Laboratory. NREL/TP-6A20-73908. https://www.nrel.gov/docs/fy19osti/73908.pdf.

Munday, Max, Gill Bristow, and Richard Cowell. 2011. "Wind farms in rural areas: How far do community benefits from wind farms represent a local economic development opportunity?" Journal of Rural Studies 27, no. 1: 1-12. https://www.sciencedirect.com/science/article/pii/S0743016710000549.

National Association of State Energy Officials (NASEO) and Energy Futures Initiative (EFI). 2019. The 2019 U.S. Energy \& Employment Report. BW Research Partnership. https://static1.squarespace.com/static/5a98cf80ec4eb7c5cd928c61/t/5c7f3708fa0d6036d7120d8f/ 1551849054549/USEER+2019+US+Energy+Employment+Report.pdf.

Ray, Suparna. 2017. "Repowering wind turbines adds generating capacity at existing sites." U.S. Energy Information Administration, Office of Energy Analysis, U.S. Department of Energy. https://www.eia.gov/todayinenergy/detail.php?id=33632.

Stefek, Jeremy, Anna Kaelin, Suzanne Tegen, Owen Roberts, and David Keyser. 2019. Economic Impacts from Wind Energy in Colorado Case Study: Rush Creek Wind Farm. Golden, CO: National Renewable Energy Laboratory. NREL/TP-5000-73659. https://www.nrel.gov/docs/fy19osti/73659.pdf.

Tegen, Suzanne, David Keyser, Francisco Flores-Espino, and Rachel Hauser. 2014. Economic Impacts from Indiana's First 1,000 Megawatts of Wind Power. Golden, CO: National Renewable Energy Laboratory. NREL/TP-5000-60914. https://www.nrel.gov/docs/fy14osti/60914.pdf.

U.S. Bureau of Labor Statistics. 2019. "Median age of the labor force by sex, race, and ethnicity." Office of Occupational Statistics and Employment Projections. https://www.bls.gov/emp/tables/median-age-labor-force.htm. 
U.S. Energy Information Administration. 2019a. "Existing Net Summer Capacity of Other Renewable Sources by Producer Type, 2008 through 2018 (Megawatts).” Office of Energy Analysis, U.S. Department of Energy.

https://www.eia.gov/electricity/annual/html/epa_04_02_b.html.

U.S. Energy Information Administration. 2019b. Annual Energy Outlook 2019. Office of Energy Analysis, U.S. Department of Energy. https://www.eia.gov/outlooks/aeo/pdf/aeo2019.pdf.

U.S. Energy Information Administration. 2019c. "Net Generation by Energy Source: Total (All Sectors), 2010-August 2020.” Office of Energy Analysis, U.S. Department of Energy. https://www.eia.gov/electricity/monthly/epm_table_grapher.php?t=epmt_1_01.

Wiser, Ryan, and Mark Bolinger. 2018. 2017 Wind Technologies Market Report. U.S. Department of Energy Office of Energy Efficiency and Renewable Energy.

https://www.energy.gov/sites/prod/files/2018/08/f54/2017 wind technologies market report 8 . 15.18.v2.pdf. 


\section{Appendix A. Employee Survey Instrument}

The following are screenshots of the employee survey instrument that was distributed by BW Research between August and September of 2019.

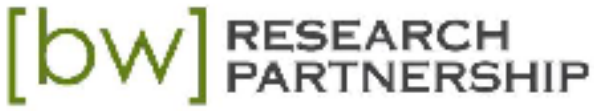

NREL Wind EIR Research

Employee Survey - August 2019

Draft 2.0

$\cdots$

Introduction:

Hello, may I please speak to . $\mathrm{Hi}$, my name is and I'm with an independent research firm, BW Research, that is working to better understand the nature of employment in your community.

(If needed): This should only take a few minutes of your time.

(If needed): I assure you that we are an independent research agency and that all of your responses will remain strictly confidential.

(If needed): This is a study about issues of importance in your community - it is a survey only and we are not selling anything.

(If needed): This survey should only take a few minutes of your time.

(If respondent indicates that he/she is a city employee, council member, or elected official, thank him/her for his/her time and end the interview.)

(If the individual mentions the national do not call list, respond according to American Marketing Association guidelines): "Most types of opinion and marketing research studies are exempt under the law that congress recently passed. That law was passed to regulate the activities of the telemarketing industry. This is a legitimate research call. Your opinions count!" )

Screener Questions

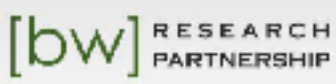




\section{Wind Operations and Maintenance Research}

October 2019

SA. Are you currently employed at wind plant facility?

$\begin{array}{ll}1 & \text { Yes } \\ 2 & \text { No [Thank and terminate] }\end{array}$

SB. What is the zip code where you live?

1 Note zip codes (THAT ARE WITHIN 15 miles of wind plant facility - WITHIN)

2 Note zip codes (THAT ARE OUTSIDE 15 miles of wind plant facility OUTSIDE)

3 Don't know/ refused [Thank and terminate]

SC. What year were you born?

[RECORD YEAR AND CATEGORIZE]

1 Less than 18 years old [Thank and terminate]

218 to 24 years old (Gen Z - Post-Millennial)

325 to 31 years old (Young Millennial)

432 to 39 years old (Older Millennial)

540 to 47 years old (Young Gen X)

648 to 55 years old (Older Gen X)

756 to 64 years old (Baby boomer)

865 years or older (Thank and terminate)

9 Don't know/ refused [Thank and terminate]

SD. What is the last grade you completed in school?

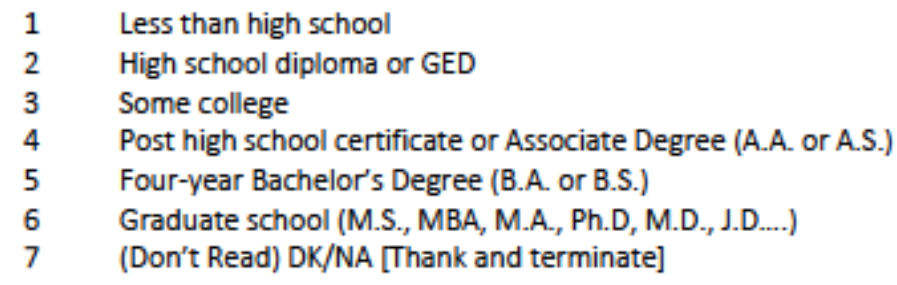

IF SD=4, 5 OR 6 ASK SE OTHERWISE SKIP

SE. Did you get a degree or certificate in a specific wind program?

1 No, I did not receive a wind specific certificate or degree

2 Yes, I received a wind specific certificate or degree from a program near the wind plant 


\section{Wind Operations and Maintenance Research}

October 2019

3 Yes, I received a wind specific certificate or degree but from a program outside the area and not near the wind plant

SF. Are you currently employed at wind plant facility, on a permanent full-time, permanent part-time, or on a temporary or seasonal basis? (ALLOW MORE THAN ONE RESPONSE]

1 Permanent full-time (at least 35 hours a week)

2 Permanent part-time (less than 35 hours a week)

3 Temporary or seasonal

4 Contractor

5 None of them [Thank and terminate]

6 (Don't Read) DK/NA [Thank and terminate]

\section{Introduction - Work Profile}

I want to start with a few quick questions about employment.

1. How long have you worked at wind plant facility?

$\begin{array}{ll}1 & \text { Less than } 6 \text { months } \\ 2 & 6 \text { months to a year } \\ 3 & \text { More than a year up to } 3 \text { years, } \\ 4 & \text { More than } 3 \text { years up to } 5 \text { years } \\ 5 & \text { More than } 5 \text { years } \\ 6 & \text { Not sure (DK/NA) }\end{array}$

2. How long have you held your current position at the facility?

$\begin{array}{ll}1 & \text { Less than } 6 \text { months } \\ 2 & 6 \text { months to a year } \\ 3 & \text { More than a year up to } 3 \text { years, } \\ 4 & \text { More than } 3 \text { years up to } 5 \text { years } \\ 5 & \text { More than } 5 \text { years } \\ 6 & \text { Not sure (DK/NA) }\end{array}$

3. How long do you expect you will work with your current employer? 
4. What is your occupation or positional title?

5. Which of the following benefits do you receive from working at the wind plant facility? (ALLOW MULTIPLE RESPONSE)

1 Medical insurance for yourself

2 Medical insurance for your household

3 Dental insurance for yourself

4 Dental insurance for yourself

$5401 \mathrm{k}$ or related retirement account that the employer contributes to

6 Paid time off

7 Other (specify

8 None of the above

\section{COMMUTE AND SPENDING PROFILE}

6. How long have you lived in your current community in $\mathrm{SB})$ ? (USE ZIP CODE IN

$\begin{array}{ll}1 & \text { Less than } 6 \text { months } \\ 2 & 6 \text { months to a year } \\ 3 & \text { More than a year up to } 3 \text { years, } \\ 4 & \text { More than } 3 \text { years up to } 5 \text { years } \\ 5 & \text { More than } 5 \text { years } \\ 6 & \text { Not sure (DK/NA) }\end{array}$

7. How long do you expect you will live at your current residence (IF NEEDED, IDENTIFY ZIP CODE IN SB)?

1 Less than 6 months

26 months to a year

3 More than a year up to 3 years,

4 More than 3 years 
8. Now l'm going to read a list of statements that describe how people spend their time and money within and outside of work. Please indicate whether you generally agree, disagree, or neither agree nor disagree with the following statements.

Here is the (first/next) one:

Do you generally agree, disagree or neither agree nor disagree with the statement? (GET ANSWER IF AGREE OR DISAGREE ASK:) Would that be strongly (agree/disagree) or somewhat (agree/disagree)?

RANDOMIZE

\begin{tabular}{|c|c|c|c|c|c|}
\hline $\begin{array}{l}\text { Strongly } \\
\text { Apres }\end{array}$ & $\begin{array}{l}\text { Somewhat } \\
\text { Arres }\end{array}$ & $\begin{array}{l}\text { Neither } \\
\text { Agree nor } \\
\text { Disagres }\end{array}$ & $\begin{array}{l}\text { Somewhat } \\
\text { Disagres }\end{array}$ & $\begin{array}{l}\text { Strongly } \\
\text { Disagres }\end{array}$ & $\begin{array}{r}\text { (DONT) } \\
\text { READ) } \\
\text { DE/NA }\end{array}$ \\
\hline \multicolumn{6}{|l|}{ A. I work at the wind plant facility five days } \\
\hline a week on a normal work week ............. 1 & 2 & 3 & 4 & 5 & 6 \\
\hline \multicolumn{6}{|l|}{ B. My daily commute to work takes more than } \\
\hline 30 minutes each way & 2 & 3 & 4 & 5 & 6 \\
\hline \multicolumn{6}{|c|}{ C. When I am not at work, I spend most of my time and } \\
\hline Money where I live & 2 & 3 & 4 & 5 & 6 \\
\hline \multicolumn{6}{|c|}{ D. Most, if not all of my professional work experience is in the } \\
\hline Wind industry & 2 & 3 & 4 & 5 & 6 \\
\hline \multicolumn{6}{|c|}{ E. When I am at work or right after work, I spend most of my time and money in } \\
\hline the communities near the wind plant ....1 & 2 & 3 & 4 & 5 & 6 \\
\hline \multicolumn{6}{|c|}{ I am in a career pathway in the wind industry that I expect to build upon } \\
\hline For at least the next 5 years & 2 & 3 & 4 & 5 & 6 \\
\hline
\end{tabular}

9. What are the primary reasons you live in your current community in (USE ZIP CODE IN SB)? (ALLOW MORE THAN ONE RESPONSE)

To wrap things up, I just have a few background questions for statistical purposes only.

A. Do you own or rent the unit in which you live?

$\begin{array}{ll}1 & \text { Rent } \\ 2 & \text { Own } \\ 3 & \text { Neither rent nor own } \\ 4 & \text { Don't know/ Refused }\end{array}$

B. How many children under 19 years of age live in your household?

$$
1 \text { None (\# of children living in the household under } 19 \text { years old) }
$$


C. Including yourself, how many adults 19 years of age or older live in your household? [\# of adults living in the household 19 years old or older)

2 Don't know/ Refused

D. Are there any languages spoken in your home other than English? (If yes, which ones?)

1 Yes (please specify:

2 No

3 (Don't Read) Refused

E. What ethnic group do you consider yourself a part of or feel closest to? (IF HESITATE, READ):

$\begin{array}{ll}1 & \text { Pacific Islander } \\ 2 & \text { Black or African American } \\ 3 & \text { Hispanic or Latin(o)a } \\ 4 & \text { Asian } \\ 5 & \text { White } \\ 6 & \text { American Indian/Alaskan Native } \\ 7 & \text { Other (Please specify: } \\ 8 & \text { (Don't Read) DK/NA }\end{array}$

F. What is your Gender?

$\begin{array}{ll}1 & \text { Male } \\ 2 & \text { Female } \\ 3 & \text { Non-Binary }\end{array}$

G. What is your annual or hourly take home pay?

Annual $\$$ $\infty 00$ Hourly \$

IF NOT COMFORTABLE WITH SPECIFIC AMOUNT PLEASE IDENTIFY CATEGORY THAT FITS YOUR ANNUAL TAKE HOME PAY?

$\begin{array}{ll}1 & \text { Below } \$ 25,000 \\ 2 & \$ 25,000 \text { to } \$ 50,000 \\ 3 & \$ 50,001 \text { to } \$ 75,000 \\ 4 & \$ 75,001 \text { to } \$ 100,000 \\ 5 & \$ 100,001 \text { to } \$ 199,000\end{array}$


$6 \quad$ More than $\$ 200,000$

I don't know

H. What was your total household income before taxes from last year.

$\begin{array}{ll}1 & \text { Below } \$ 25,000 \\ 2 & \$ 25,000 \text { to } \$ 50,000 \\ 3 & \$ 50,001 \text { to } \$ 75,000 \\ 4 & \$ 75,001 \text { to } \$ 100,000 \\ 5 & \$ 100,001 \text { to } \$ 199,000 \\ 6 & \text { More than } \$ 200,000 \\ 7 & \text { I don't know }\end{array}$

Those are all of the questions we have for you. Thank you very much for participating!

First Name of Respondent

Phone

Date of Interview

Name of Interviewer

Time of Interview

Type of Interview

1 Online Employer-invite

2 Online email-invite

3 Phone 


\section{Appendix B. Structured Interview for Employers}

The following are screenshots of the structured interview for employers that was distributed by BW Research between August and September of 2019.

We are contacting you as part of an effort by the National Renewable Energy Laboratory (NREL) to quantify the positive economic impacts of wind energy on local \{INSERT STATE\} communities. The \{INSERT WIND PLANT\} wind plant has been identified by NREL and BW Research as one of sixteen preferred candidates for case studies. The findings of this research will be published in a report, informing community-level stakeholders about wind plant O\&M and the level of economic impacts on nearby communities.

Would you happen to have any time to discuss the operations of \{INSERT WIND PLANT\} over the next week? We are offering compensation in the form of a $\$ 50$ Amazon Gift Card for your time.

(If needed): Depending on your input, this discussion could take anywhere from 10 to 20 minutes of your time.

As a follow-up to your interview, we would ask that a short online workforce survey is shared with your employees so that we can gather additional information about commuting times, local spending, etc. Your employees will be compensated with a \$25 Amazon Gift Card for their participation. All responses for this case study will remain CONFIDENTIAL and will only be shared in the aggregate.

A. Are you willing to share the survey link with your employees?

1. Yes [SKIP TO S1]

2. No [ASK SCREENER B]

ASK SCREENER B IF SCREENER A=2

B. Are you willing to share a list of employee emails for our distribution? 
1. Yes [CONTINUE]

2. No [CONTINUE]

Let's go ahead and begin.

$\ldots$

\section{SHORT PROFILE ON EACH RESPONDENT}

S1. Name of Individual:

S2. Name of Company:

S3. Contact information phone:

Email:

S4. Date \& Time of Interview:

S5. Firm Size (Employees managed by owning/controlling organization - Based on Secondary Data and Working at or from location FTP)
A. Small -1 to 9
B. Medium -10 to 99
C. Large $-100+$

S6. Wind Farm Ownership
A. Utility-Owned
B. Investor-Owned
C. Community-Owned
D. Developer-Owned

S8. How Long has wind farm location been in operation
A. 0 to 2 years 
B. $2+$ to 5 years

C. $5+$ to 10 years

D. $10+$ to 20 years

E. $20+$ years

S9. Geographic location?
A. Zip Code
B. County
C. State

I. Profile \& General Information [FILL OUT IN ADVANCE AS INFORMATION IS AVAILABLE]

Let me begin by asking a few general questions about you and [NAME OF ORGANIZATION]

1. What is your title or position within the firm?

[Record title]

2. How long have you been with the organization?

[Record years / months]

3. What role do you play at the organization?

4. What location(s) does your firm have for commercial wind farms? (BY ZIP CODE PREFERRED)

\section{EMPLOYMENT PROFILE}


[REMINDER = PLEASE NOTE THE LOCATION WE WILL BE FOCUSING ON FOR THE
REMAINDER OF THE CONVERSATION IS THE WIND FARM AT__ LOCATION]

The next few questions are about trying to better understand the size and scope of people that work at or provide services at your current wind farm location.

Thinking about anyone that works at your location, let's categorize them into three groups.

Group ONE - are those permanent employees (Full-Time or Part-Time) that work at or from your location and are employed by your organization.

Group TWO - are those temporary, seasonal, or on-call employees (Full-time or partTime) that are employed by your organization but are not on employed on a permanent basis.

Group THREE - are those people that work at your location but are ultimately employed by a vendor or supplier organization, who provides contracted out services for your organization.

5. Including all full-time and part-time employees, how many permanent [IF NEEDED: PERMANENT EMPLOYEES INCLUDE THOSE WORKERS WHO ARE NOT TEMPORARY, SEASONAL OR ON A CONTRACT FOR A LIMITED PERIOD OF TIME - GROUP ONE] employees work at or from your current location?

Record \# of employees

[IF UNABLE TO PROVIDE NUMBER, OFFER INTERVALS]

$\begin{array}{ll}1 & \text { Fewer than } 5 \\ 2 & \text { Between } 5 \text { and } 9 \\ 3 & \text { Between } 10 \text { and } 24 \\ 4 & \text { Between } 25 \text { and } 49 \\ 5 & \text { Between } 50 \text { and } 99 \\ 6 & 100 \text { or more } \\ 7 & \text { (DON'T READ) DK/NA }\end{array}$

6. If you currently have [TAKE Q5 \#] full-time and part-time permanent employees at your current location, how many more or less employees do you expect to have 12 months from now?

$\begin{array}{ll}1 & \text { More [record \#__ } \\ 2 & \text { Less [record \#__ }\end{array}$




\section{Wind Operations and Maintenance Research}

October 2019

3 (DON`T READ) Same number of employees

4 (DON'T READ) Refused

[If amount differs by $10 \%$ or more in either direction, ask: ]

Just to confirm, you currently have ___ permanent employees and you expect to have

employees, for a total of employees 12 months from now. [more/less]

7. Over the last three years, has your company grown, declined or stayed about the same in terms of permanent employment at your location? [If it has grown or declined, ask] By about how many people?

$\begin{array}{ll}1 & \text { Grown by _ total employees } \\ 2 & \text { Stayed the same } \\ 3 & \text { Declined by } \\ 4 & \text { [DON'T READ] DK/NA }\end{array}$

8. What are the primary job positions, categories or classifications that your location employs for permanent employment? (IF NEEDED - THIS IS FOR PERMANENT GROUP ONE EMPLOYEES)

9. Thinking of those permanent group one employees, how often do they live within the community of your current location? [IF NEEDED: THIS WOULD BE A ONE-WAY COMMUTE OF MORE THAN 20 MINUTES OR MORE THAN 15 MILES FROM YOUR LOCATION]

1. Usually ( $70 \%$ of the time or more)

2. Frequently ( $31 \%$ to $69 \%$ of the time)

3. Seldom ( $1 \%$ to $30 \%$ of the time)

4. Never

5. DK/NA [DON'T READ]

10. How many or what percentage of your permanent or group one employees are union members?
1. All (100\%)
2. Most (99\% to 61\%)
3. About Half ( $60 \%$ to $40 \%$
4. Less than half ( $39 \%$ to $1 \%)$
5. None (0\%)
6. DK/NA [DON'T READ] 
Now I would like to ask the same questions about temporary, seasonal, or on-call workers who are working for a limited period of time but are employed by your organization. This would be the group two employees that are employed by your organization but not on a permanent basis.

11. Including all full-time and part-time employees, how many temporary, seasonal, or on-call workers [IF NEEDED: THIS IS NON-PERMANENT EMPLOYEES] employees work at or from your current location?

Record \# of employees

[IF UNABLE TO PROVIDE NUMBER, OFFER INTERVALS]

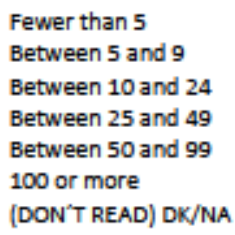

12. If you currently have [TAKE Q8 \#] full-time and part-time temporary, seasonal, or oncall employees at your current location, how many more or less employees do you expect to have 12 months from now?

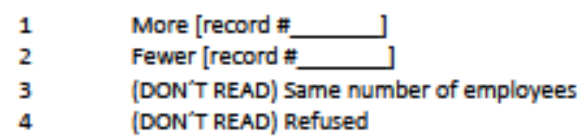

[If amount differs by $10 \%$ or more in either direction, ask: ] Just to confirm, you currently have permanent employees and you expect to have (more/fewer) employees, for a total of ___ employees 12 months from now.

13. Over the last three years, has your company grown, declined or stayed about the same in terms of temporary, seasonal, or on-call employment at your location? [If it has grown or declined, ask] By about how many people?

$\begin{array}{ll}1 & \text { Grown by _ } \\ 2 & \text { Stayed the same } \\ 3 & \text { Declined by } \\ 4 & \text { [DON'T READ] DK/NA }\end{array}$


14. What are the primary job positions, categories or classifications that your location employs for nonpermanent employment? (IF NEEDED - THIS IS FOR TEMPORARY, SEASON OR ON_CALL EMPLOYEES GROUP TWO EMPLOYEES)

15. Thinking of those non-permanent group two employees, how often do they live within the community of your current location? [IF NEEDED: THIS WOULD BE A ONE-WAY COMMUTE OF MORE THAN 20 MINUTES OR MORE THAN 15 MILES FROM YOUR LOCATION]

1. Usually ( $70 \%$ of the time or more)

2. Frequently ( $31 \%$ to $69 \%$ of the time)

3. Seldom ( $1 \%$ to $30 \%$ of the time)

4. Never

5. DK/NA [DON'T READ]

16. How many or what percentage of your temporary or group two employees are union members?
7. All (100\%)
8. Most (99\% to $61 \%)$
9. About Half ( $60 \%$ to $40 \%$
10. Less than half ( $39 \%$ to $1 \%)$
11. None $(0 \%)$
12. DK/NA [DON'T READ]

Lastly, I would like to ask about people that work at your location but would not be your employees. GROUP THREE EMPLOYEES

17. Do you have contracts or agreements with other firms, suppliers or vendors to provide cleaning. maintenance, or other work at your location?
1. Yes
2. No
3. (Don't Read) DK/NA

[IF Q17 = 1, ASK Q18 \& Q19, OTHERWISE SKIP]

18. Please describe the number of agreements and the type of work that is provided at your location?

\section{$[$ OW] RESEARCH}




\section{Wind Operations and Maintenance Research}

October 2019

19. Generally, describe what percentage or portion of work is done by your locational employees and the service or contract provider for each agreement?

\section{[ASK FOR EACH AGREEMENT IDENTIFIED IN Q18]}

1. All of it is provided by the contract provider including supervision and QC (100\%)

2. Most of it is provided by the contract provider ( $99 \%-61 \%)$

3. About half of it is provided by the contract provider ( $60 \%$ to $40 \%$ )

4. Less than half of it is provided by the contract provider (1\% to $39 \%$ of the time)

5. DK/NA [DON'T READ]

20. In general, are your vendors and suppliers for this location primarily local - within the county, regional - within the region, Statewide - within the state, national - within the Country, or international - outside the Country? [UP TO 2 RESPONSES PERMITTED]

$\begin{array}{ll}1 & \text { Local - County } \\ 2 & \text { Regional - Within Region } \\ 3 & \text { Statewide - Within State } \\ 4 & \text { National - Within the United States } \\ 5 & \text { International - Outside the United States } \\ 6 & \text { (Don't Read) Don't know }\end{array}$

\section{General Hiring Behavior and Priorities}

Next I want to briefly ask your hiring processes and priorities -

21. How do you look for and recruit qualified applicants? [WAIT FOR INITIAL RESPONSE AND THEN PROBE ON]
a. Online tools (job boards, be specific...)
b. Person to person networks or referrals
c. Internal HR tools (recruitment process, evaluation process, ...)
d. Local Schools (High School or College) and educational/workforce training programs
e. Other (please specify)

22. Thinking about those positions at your current location in general, how much difficulty does your organization have finding qualified applicants who meet the organization's hiring standards?
1. Little to no difficulty
2. Some difficulty
3. Great difficulty
4. (Don't Read) DK/NA

[IF Q20 = 2 OR 3, ASK Q21, OTHERWISE SKIP] 
23. Why do you think you have difficulties finding qualified applicants (WAIT FOR RESPONSE AND THEN PROBE ON GEOGRAPHY, Salary Requirements - DO THEY HIRE OUTSIDE OF THE COMMUNITY IS YES WHY)?

24. Please describe any positions, skills or areas of expertise that are particularly difficult to find among job applicants when hiring for the current location?

25. Now I want to ask you about retaining or keeping employees at your current location in general, how much difficulty does your organization have retaining productive employees who work at or from your location?

1. Little to no difficulty

2. Some difficulty

3. Great difficulty

4. (Don't Read) DK/NA

[IF Q23 = 2 OR 3, ASK Q24, OTHERWISE SKIP]

26. Why do you think you have difficulties retaining or keeping productive employees (WAIT FOR RESPONSE AND THEN PROBE ON GEOGRAPHY, SKILLS AND TRAINING AND EXPERTISE, Other Industries)?

Lastly, I want to ask about the impact your wind farm location has on the surrounding community.

27. Does your wind farm provide any additional support to the community, such as supporting schools, community events other community or regional contributions?

28. Is there any other information that we should be aware of as we estimate the economic impact your location has on the local, regional and national economy? 
29. Do we have your permission to share your name and organization with NREL, who is ultimately using this research to better understand organizations like yours.
A. Yes, share my name and organization
B. Only share my organization
C. No, do not share my name or organization

\section{IF SCREENER B=1 ASK Q30}

30. Will you be willing to share a list of employee emails over email?

1. Yes [THANK AND END SURVEY]

2. No [COLLECT EMAILS OVER THE PHONE]

IF SCREENER A = 1, SHARE EMPLOYEE SURVEY UNK WITH RESPONDENT FOR DISTRIBUTION

COLLECT EMAIL FOR AMAZON GIFT CARD AND TO SHARE SURVEY LINK (IF REQUESTED) - IF WILLING TO SHARE LIST OF EMPLOYEES, SHARE RYOUNG@BWRESEARCH.COM WITH RESPONDENT SO THAT THEY CAN SEND LIST

WE WILL BE WORKING TO COMPLETE A SHORT SURVEY WITH YOUR EMPLOYEES TO BETTER UNDERSTAND THEIR ECONOMIC IMPACT ON THE SURROUNDING REGION 


\section{Appendix C. Surveyed Wind Facilities}

The following is a list of the wind power plants that participated in the BW Research elicitation.

1. Amazon Wind U.S. East - North Carolina - Southeast - 208 megawatts (MW)

a. Completed operation and maintenance (O\&M) executive interview

b. Waiting for employee survey approval from human resources (HR)

2. El Cabo - New Mexico - Interior - 298.2 MW

a. Completed O\&M executive interview

b. Waiting for employee survey approval from HR

3. Glenrock III - Wyoming - Interior - $39 \mathrm{MW}$

a. Completed O\&M executive interview

b. Four completed employee interviews

4. Horse Butte - Idaho - West - 57.6 MW

a. Completed O\&M executive interview

b. One completed employee interview

5. Manzana Winds - California - West - 189 MW

a. Completed O\&M executive interview

b. Waiting for employee survey approval from HR

6. Twin Buttes II - Colorado - Interior - $75 \mathrm{MW}$

a. Completed O\&M executive interview

b. Waiting for employee survey approval from HR

7. Beech Ridge - West Virginia - Southeast - 100.5 MW

a. Completed O\&M executive interview

b. Nine completed employee interviews

8. CONFIDENTIAL - Interior $->100 \mathrm{MW}$

a. Completed O\&M executive interview

b. Two completed employee interviews

9. CONFIDENTIAL - West $->100 \mathrm{MW}$

a. Completed O\&M executive interview

b. 10 completed employee interviews

10. CONFIDENTIAL - West $-<100 \mathrm{MW}$

a. Completed O\&M executive interview

b. Declined employee interviews

11. CONFIDENTIAL - Interior $->100 \mathrm{MW}$

a. Completed O\&M executive interview

b. Three completed employee interviews 